\title{
Pharmacological Characterization of Sigma-2 Preferring Compounds: Implications in Cocaine-induced Behaviors
}

Bahar Noorbakhsh

West Virginia University

Follow this and additional works at: https://researchrepository.wvu.edu/etd

\section{Recommended Citation}

Noorbakhsh, Bahar, "Pharmacological Characterization of Sigma-2 Preferring Compounds: Implications in Cocaine-induced Behaviors" (2012). Graduate Theses, Dissertations, and Problem Reports. 4905. https://researchrepository.wvu.edu/etd/4905

This Thesis is protected by copyright and/or related rights. It has been brought to you by the The Research Repository @ WVU with permission from the rights-holder(s). You are free to use this Thesis in any way that is permitted by the copyright and related rights legislation that applies to your use. For other uses you must obtain permission from the rights-holder(s) directly, unless additional rights are indicated by a Creative Commons license in the record and/ or on the work itself. This Thesis has been accepted for inclusion in WVU Graduate Theses, Dissertations, and Problem Reports collection by an authorized administrator of The Research Repository @ WVU. For more information, please contact researchrepository@mail.wvu.edu. 
Pharmacological Characterization of Sigma-2 Preferring Compounds:

Implications in Cocaine-induced Behaviors

Bahar Noorbakhsh

Thesis submitted to the

School of Pharmacy

at West Virginia University

in partial fulfillment of the requirements

for the degree of

Master of Science
in

Biomedical Sciences

Rae R. Matsumoto Ph.D., Chair

William P. Petros, Pharm.D.

Carl R. Sullivan, M.D.

Program in Pharmaceutical and Pharmacological Sciences

Morgantown, West Virginia

2012

Key Words: Cocaine; Convulsions; Locomotor; Sigma Receptors

Copyright 2012 Bahar Noorbakhsh 


\section{ABSTRACT \\ Pharmacological Characterization of Sigma-2 Preferring Compounds: Implications in Cocaine-induced Behaviors}

\section{Bahar Noorbakhsh}

Cocaine is a powerful psychostimulant that is highly abused by 1.9 million people in the United States. It accounts for more emergency department visits than any other illicit drug. Even with the high rate of cocaine abuse, no FDA approved pharmacological treatments exist. Many attempts at finding a pharmacotherapy for cocaine abuse and addiction have been made, but proven unsuccessful. Cocaine is known to bind sigma receptors at physiologically relevant concentrations, deeming them potential targets for cocaine pharmacotherapies and helping to elucidate the actions of cocaine. Two subtypes of sigma receptors have been described, sigma-1 and sigma-2. Minimal information is known about the function of sigma- 2 receptors in relationship to cocaine-induced effects. This is attributed to the inability to clone the subtype and the absence of highly selective ligands. In the present study four novel compounds (CM699, CM398, CM777 and CM775) were found through radioligand binding assays, in rat brain homogenates and liver P2 membrane (with the exception of opioid receptors in $\mathrm{CHO}$ cells), to possess substantially high affinities for sigma-2 receptors versus sigma-1 and non-sigma receptor sites. Behavioral studies, performed in male, Swiss-Webster mice, showed that pretreatment of CM398, CM777 and CM775 to a convulsive or stimulatory locomotor dose of cocaine led to significant attenuation of cocaine-induced convulsions and hyperactivity. Additionally, administration of pretreatment doses of CM699 to nonconvulsive doses of cocaine led to the occurrence or exacerbation of cocaine-induced convulsions. The availability of these sigma-2 receptor preferring compounds provide pharmacological tools to elucidate the relationship between sigma-2 receptors and cocaine effects. Furthermore, these ligands present promising putative pharmacological treatments for cocaine abuse and addiction. 


\section{ACKNOWLEDGEMENTS}

I would like to thank my committee members Dr. Rae Matsumoto, Dr. William Petros and Dr. Carl Sullivan for their guidance and assistance throughout my time here.

Thank you to the most supportive and loving family I could have ever asked for, my mom, dad, brother and sister-in-law. Words cannot express my appreciation and love for everything they have done for me. I am also thankful for the love and support, my newly acquired family, the Mihalcins, have given me.

I am incredibly grateful and indebted to my husband, Andrew, who has been with me from the beginning of this journey. I can say with the utmost sincerity that without his love, support, guidance, patience, understanding, devotion and ability to dry tears, I would have never made it this far. I can never thank him enough for sympathizing in my disappointments but importantly sharing in my joys.

I would like to extend my gratitude to all the Matsumoto lab members, particularly Matthew Robson and Michael Seminerio, for their help, advice, knowledge and support. Special thanks to Mike, who was not just a colleague but a best friend that was always there for me and stuck by my side when no one else did.

Lastly, I want to thank Alisa Elliott, Courtney Pawlak and Amanda Suchanek who provided me a network of encouragement, advice and comic relief. They taught me the true meaning of friendship is dropping everything in a second, no matter the time of day, if a friend is in need. 


\section{TABLE OF CONTENTS}

PHARMACOLOGICAL CHARACTERIZATION OF SIGMA-2 PREFERRING COMPOUNDS: IMPLICATIONS IN COCAINE-INDUCED BEHAVIORS..........i

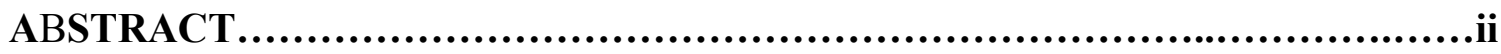

ACKNOWLEDGEMENTS................................................................

TABLE OF CONTENTS...............................................................

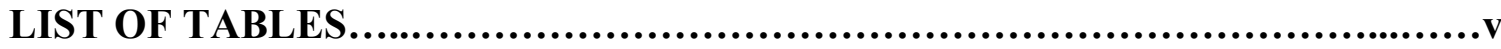

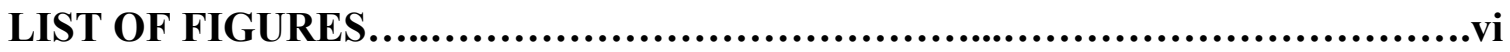

ABBREVIATIONS.....................................................................ii

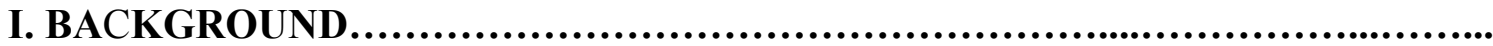

A. Cocaine

B. Sigma Receptors.

B.1 Sigma-1 Receptors

B.2 Sigma-2 Receptors

C. Sigma Receptors and Cocaine

D. Sigma-2 Receptor Ligands.

E. Statement of Problem.

F. Specific Aims.

II. MATERIALS AND METHODS.
A. Drugs and Chemicals
B. Animals.
C. Radioligand Binding Assays
D. Cocaine-induced Convulsions
E. Locomotor Activity.
F. Data Analysis.

III. RESULTS.
A. Receptor Binding Affinities
B. Cocaine-induced Convulsions
C. Locomotor Activity.

IV. DISCUSSION

V. CONTRIBUTIONS

VI. REFERENCE LIST.

VII. CURRICULUM VITAE. 
VIII. APPROVAL PAGE............................................................ 


\section{LIST OF TABLES}

Table 1. Binding affinities of CM699, CM398, CM777 and CM775.

Table 2. Binding affinities of sigma reference ligands, CM699, CM398 and CM775 in liver and brain. 


\section{LIST OF FIGURES}

Fig. 1. Functional group substitutions at the $R^{1}, R^{2}$ and $R^{3}$ positions.

Fig. 2. Chemical structures of novel ligands.

Fig. 3. Correlation plot of sigma receptor binding affinities in brain and liver membrane.

Fig. 4. The effects of cocaine, CM398, CM777, and CM775 on convulsions.

Fig. 5. The effects of cocaine and CM699 on convulsions.

Fig. 6. The effects of cocaine, CM398, CM777, and CM775 on locomotor activity. 


\section{ABBREVIATIONS}

(士)-SM21

5-HT2

ANOVA

CB-64D

CB-184

CHO

CM398

CM699

CM775

CM777

D2

DAMGO

DAT

DPDPE

DTG

IACUC

MK-801

NET

NMDA

PEI

RHM-4 3alpha-tropanyl-2-(4-chorophenoxy)butyrate

Serotonin receptor

Analysis of variance

(+)-1R,5R-(E)-8-Benzylidene-5-(3-hydroxyphenyl)-2methylmorphan-7- one

(+)-1R,5R-(E)-8-(3,4-dichlorobenzylidene)-5-(3-hydroxyphenyl)2-++ +methylmorphan-7 - one

Chinese hamster ovary

1-(4-(6,7-dimethoxy-3,4-dihydroisoquinolin-2(1H)-yl)butyl)-3methyl-1H-benzo[ $[d]$ imidazol-2(3H)-one

1-(4-(3H-spiro[isobenzofuran-1,4'-piperidin]-1' -yl)butyl)-3methyl-1H-benzo $[d]$ imidazol-2(3H)-one

1-(4-(4-(4-flurophenyl)piperazin-1-yl)butyl)-3-pentyl-1Hbenzo $[d]$ imidazol-2(3H)-one

1-(4-(4-(4-flurophenyl)piperazin-1-yl)butyl)-3-propyl-1Hbenzo $[d]$ imidazol-2(3H)-one

Dopamine receptor

[D-Ala ${ }^{2}, \mathrm{~N}-\mathrm{MePhe}^{4}$, Gly-ol]-enkephalin

Dopamine transporter

$\left[\mathrm{D}-\mathrm{Pen}^{2,5}\right]$-enkephalin

Di-o-tolylguanidine

Institutional Animal Care and Use Committee

(+)-5-methyl-10,11-dihydro-5H-dibenzo[a,d]cyclohepten-5,10imine maleate)

Norepinephrine transporter

N-methyl-D-aspartate

Polyethyleneimine

$N$-(4-(6,7-Dimethoxy-3,4-dihydroisoquinolin-2(1H)-yl)butyl)-2-(2fluoroethoxy)-5-iodo-3-methoxybenzamide 
SAR

S.E.M.

SERT

SPC

TCP

U69, 593

UMB24

WC-59

WIN35,428
Structure-activity relationship

Standard error of the mean

Serotonin transporter

Sphingosylphosphorylcholine

\section{Tenocyclidine}

N-methyl-2-phenyl-N-[(5R,7S,8S)-7-pyrrolidin-1-yl-1oxaspiro[4.5]decan-8-yl]acetamide

1-(2-phenethyl)-4-(2-pyridyl)-piperazine

(9-(4-(2-Fluoroethyl)benzyl)-9-azabicyclo[3.3.1]nonan-3-yl-2methoxy-5-methyl-phenylcarbamate)

(-)-2- $\beta$-Carbomethoxy-3- $\beta$-(4-fluorophenyl)tropane 


\title{
I. BACKGROUND
}

\begin{abstract}
A. Cocaine
Cocaine is a powerful and addictive stimulant that is highly abused in the United States. An estimated 1.4 million people in the United States meet the Diagnostic and Statistical Manual of Mental Disorders criteria for cocaine dependence or abuse (NIDA, 2010). Furthermore, cocaine contributes to 1 in 4 emergency department drug abuse related mentions (NIDA, 2010). Moreover, healthcare and loss of productivity costs cause cocaine use to be a huge economic burden in the United States (Office of National Drug Control Policy, 2004).
\end{abstract}

The desirable, acute effects of cocaine include: euphoria, energy and mental alertness. Furthermore, cocaine results in decreases in the need for food and sleep (NIDA, 2010). These properties contribute to the addictive nature of the drug. Yet, there are also serious medical complications caused by cocaine use. Being that it causes vasoconstriction, cocaine can result in cardiovascular complications like arrhythmias, hemorrhaging and heart attacks. Furthermore seizures, coma, strokes and convulsions have been seen with cocaine use. Fatality from this drug is often a result of cardiac and respiratory arrest (NIDA, 2010; Narayanan et al., 2011).

The 'dopamine hypothesis' is the ideology that cocaine primarily produces its' rewarding effects through the mesolimbic and mesocortical dopamine pathways in the nucleus accumbens, ventral tegmental area and front cortex (Carroll et al., 1999). Here cocaine acts as an indirect agonist, binding to DAT and preventing the reuptake of dopamine. This results in an increased dopamine concentration in the synapse leading to a prolonged and increased signal (Carroll et al., 1999). This ideology was further supported by the ability of dopamine reuptake inhibitors and dopamine receptor agonists to sustain cocaine self-administration in animals (Hiranita, 2010). Conversely, dopamine receptors antagonists were able to attenuate some of cocaine's behavioral effects in animals (Carroll et al., 1999). Thus, DAT became the focus in research of putative pharmacotherapies for cocaine use and abuse.

Early cocaine abuse pharmacotherapy research was based around the 'dopamine hypothesis. Many compounds were developed in the hopes of attenuating cocaine effects by blocking cocaine reuptake using dopamine uptake inhibitors or DAT antagonists (Carroll et al., 1999). Yet, many of these compounds actually displayed the opposite outcome by producing cocaine-like effects (Narayanan et al., 2011). Furthermore, studies using DAT knockdown and knockout showed that animals still exhibited the rewarding effects of cocaine (Itzhak et al., 1997; Tilley et al., 2009). Another putative pharmacotherapy studied was dopamine receptor antagonists but, unfortunately, these compounds showed limit success largely due to the occurrence of adverse side effects (Carroll et al., 1999). The lack of success for a pharmacotherapy targeting the dopaminergic system led to the focus of other targets, including serotonergic, noradrenergic, cholinergic, GABAergic, glutamatergic, cannabinoid and opioid systems, which have all shown to bind to cocaine (Narayanan et al., 2011). Unfortunately, these 
systems still showed limited or no clinical success in treating cocaine's addictive and rewarding properties due to low efficacy and adverse side effects (Narayanan et al., 2011).

Considering there still remains no FDA approved pharmacotherapies for cocaine abuse and addiction, there is still a need to look elsewhere for potential therapeutic targets. One receptor system that has shown to interact with cocaine at physiologically relevant concentrations is sigma receptors. The discovery of this interaction laid the groundwork for research assessing the potential of sigma receptors as targets for putative cocaine abuse pharmacotherapies (Sharkey et al., 1988).

\section{B. Sigma Receptors}

Sigma receptors were first reported in 1976 by Martin and colleagues while researching the effects of the benzomorphan, N-allyl-normetazocine (SKF 10,047) in morphinedependent and non-dependent chronic spinal dogs (Martin et al., 1976). The compound produced psychomimetic effects independent of interactions with $\mathrm{mu}(\mu)$ and kappa $(\kappa)$ opioid receptors (Martin et al., 1976). This resulted in the receptor's characterization as a sigma ( $\sigma)$ opioid subtype (Martin et al., 1976).

Further studies using (+) and (-) benzomorphan isomers showed that the sigma subtype displayed preferential affinity for the dextrorotatory rather than the levorotatory isomers, opposite of what is seen with opioid receptors $(\mathrm{Su}, 1982)$ Thus, it was determined that the sigma receptor was actually not an opioid receptor subtype (Su, 1982). Also, because (+)-SKF 10,047 bound to phencyclidine (PCP) sites found in N-methyl-D-aspartate (NMDA) glutamate receptors, it was thought that sigma receptors and these NMDA receptor/PCP binding site were identical (Mendelsohn et al., 1985). However, this proved incorrect due to selective NMDA ligands, such as MK-801, ((+)-5-methyl-10,11-dihydro$5 \mathrm{H}$-dibenzo[a,d]cyclohepten-5,10-imine maleate)) only partially displacing $(+)$-SKF 10 , 047 bound to the PCP site. This indicated that $(+)$-SKF 10,047 was binding to another site (Wong et al., 1988). These data along with further radioligand binding studies showed unique drug selectivity binding patterns that confirmed the existence of a novel and unique receptor, deemed sigma receptors ( $\mathrm{Su}, 1982)$.

Radioligand binding studies, using selective sigma ligands, helped further characterize sigma receptors. Differences in benzomorphan $(+) /(-)$-isomer binding affinities and molecular weight helped differentiate two sigma receptor subtypes, deemed sigma-1 and sigma-2 (Hellewell and Bowen, 1990). The two subtypes are not only distinguished by their drug selectivity and molecular weight but also function, tissue distribution and subcellular localization (Guitart et al., 2004).

\section{B.1. Sigma-1 Receptors}

Sigma-1 receptors are 25-29 kDa in size (Matsumoto et al., 2003). They have been cloned from various species, such as rodents and humans (Hanner et al., 1996; Kekuda et al., 1996). From the 223 amino acid sequence it has been characterized as unique protein unlike any other known receptors and is highly conserved across species and tissue types (Matsumoto, 2007). Sigma-1 receptors are highly expressed in brain, heart, liver, spleen

and GI tract tissues (Matsumoto, 2007). Though endogeneous ligands for sigma receptors have been proposed, such as progesterone and other neuroactive steroids, none have been 
confirmed (Matsumoto, 2007). Within the cell it is located on plasma membrane, mitochondrial membrane and the endoplasmic reticulm (Guitart et al., 2004).

Upon activation sigma-1 receptors translocate from the endoplasmic reticulm to the plasma or nuclear membrane and form protein-protein interactions (Hayashi and $\mathrm{Su}$, 2003; Hayashi and Su, 2007). They can then modulate signaling molecules, ion channels and G-protein-coupled receptors (GPCRs) (Matsumoto, 2009). Sigma-1 receptors have been implicated in the regulation of potassium channels, $\mathrm{IP}_{3}$-mediated calcium signaling, dopamine synthesis and release, acetylcholine synthesis and release, NMDA-mediated neurotransmitter release and muscarinic-mediated phosphoinositide turnover (Bowen, 2000; Hayashi and Su, 2007).

Initially sigma-1 receptors were elucidated through the use of highly selective ligands. The compound (+)-pentazocine is a truly selective sigma-1 agonist, amongst others, commonly used to study sigma-1 functions (Bowen et al., 1993). While compounds such as BD1063 (1-[2-(3,4-dichlorophenyl)ethyl]-4-methylpiperazine) and NE-100 (4methoxy-3-(2-phenylethoxy)-N,N-dipropylbenzene ethanamine) represent selective antagonists, along with many others, for sigma-1 receptors (Matsumoto et al., 1995; Chaki et al., 1994).

A major breakthrough for sigma receptor research was the first successful cloning of sigma-1 from guinea pig liver and subsequent mammalian membrane, which provided information about the structure and function of sigma-1 receptors (Hanner et al., 1996; Kekuda et al., 1996). Also, the availability of antisense oligodeoxynucleotides, sequencespecific antibodies and sigma-1 knockout mice has further aided in the characterization of sigma-1 receptor functions (Matsumoto, 2007).

\section{B.2. Sigma-2 Receptors}

In contrast to sigma-1, much less is known about the sigma-2 receptor subtype. The receptor has not yet been cloned but is known to be $18-22 \mathrm{kDa}$ in size (Matsumoto et al., 2003). Recently, through the labeling of sigma-2 receptors with novel sigma-2 ligands, it has been purported that the sigma-2 receptor binding site is located in the progesterone receptor membrane complex 1 (PGRMC1) (Xu et al., 2011). The findings of this study are promising in helping provide molecular biological tools to studying sigma-2 binding sites. Nonetheless, the labeling ligands used in the study are selective for sigma-2 versus sigma-1 receptors. However the selectivity and affinity of these ligands for non-sigma sites is unknown. Therefore, this causes uncertainty as to whether the binding site in PGRMC1 is indeed sigma- 2 or perhaps a different site possessing high affinity and selectivity for the labeling ligand. Thus, to validate the PGRMC1 binding, characterization of sigma-2 labeling ligands that have high binding affinity as well as high selectivity for sigma-2 versus sigma-1 and non-sigma receptor sites need to be used.

Sigma-2 receptors are highly expressed in brain, liver and gastrointestinal tract tissue while their cellular location includes mitochondria, endoplasmic reticulum, lysosomes and plasma membranes (Matsumoto, 2007; Matsumoto, 2009). Furthermore, sigma-2 receptors are present in high numbers in tumor and tumor cell lines, such as neuroblastomas, gliomas, melanomas, breast, prostate, lung and leukemia, within 
membrane lipid rafts (Gebreselassi and Bowen, 2004; Crawford and Bowen, 2002). Though sigma-1 receptors have also been seen in these cell lines, sigma-2 is much more highly expressed (Crawford and Bowen, 2002). MCF-7, a breast tumor cell line, is thought to express sigma-2 but not sigma-1 receptors (Crawford and Bowen, 2002). Moreover, levels of sigma- 2 receptors are 10 times greater in rapidly dividing versus quiescent cells (Bowen, 2007). This is in accordance to the known function of sigma-2 receptors in regulating cell proliferation and maintaining cell viability (Vilner and Bowen, 1999).

There are two ways sigma-2 receptors regulate the release of intracellular calcium, which is involved in modulation of cell proliferation and cytotoxicity (Vilner and Bowen, 1999). First, upon activation it causes a rapid, transient release of calcium from the endoplasmic reticulm (Vilner and Bowen, 1999). Second, extended activation of sigma-2 leads to a sustained release of intracellular calcium from the mitochondria that is subsequently implicated in the onset of apoptosis (Bowen, 2000). Also, activation of sigma-2 receptors causes increases in ceramide, a sphingolipid (Crawford et al., 2002). Ceramide can function to stimulate cell proliferation or induce apoptosis, though it is usually associated with the latter (Bowen, 2007). It is hypothesized sigma-2 results in the formation of ceramide through activation of enzymes that acylate sphingosine which can then go on to mediate actions involved in apoptosis (Bowen, 2007). Furthermore, it has been suggested that this activated enzyme hydrolyzes sphingomyelin forming SPC (Kita et al., 2001). SPC then aids in promoting cell proliferation and survival (Bowen, 2007). These findings suggest that sigma-2 receptors are involved in regulating cell life and death.

Due to its presence in tumor cell lines and involvement in the cell cycle, sigma-2 receptors represent potential therapeutic uses in cancer (Bowen, 2007). They have been studied as potential chemotherapies (Crawford and Bowen, 2002). Studies have shown tumor cells that develop resistance to antineoplastic agents do not show this effect with the use of sigma- 2 receptor ligands, giving promise to potential chemotherapeutic agents (Stein et al., 2004). Another therapeutic use of sigma-2 is as a non-invasive tumorimaging agent because of their high expression in tumor cell lines (Hashimoto and Ishiwata, 2006).

Though still unclear, sigma-2 receptors are involved in the effects of drug abuse, similar to sigma-1 receptors (Narayanan et al., 2011). Sigma-2 receptor activation has shown to enhance dopamine release caused by the presence of amphetamine (Izenwasser et al., 1998). One hypothesized mechanism is activation of the receptor results in the reversal of membrane transporters causing more dopamine to be taken out of the cell (Izenwasser et al., 1998). Another explanation is activation of sigma-2 receptors increase amphetamine uptake into intracellular vesicles by the regulation of intracellular calcium pools (Izenwasser et al., 1998). Much remains to be elucidated about sigma-2 involvement in dopamine regulation of amphetamine in addition to other drugs, like cocaine, that utilize dopaminergic systems.

The paucity in molecular and pharmacological tools makes it difficult to study the effects of sigma-2 receptors in the actions of abused drugs. It is crucial to study both sigma receptor subtypes when targeting them for putative drug abuse pharmacotherapies. This 
will help provide information in the pharmaceutical design of the drugs as to which sigma subtype(s) should/should not be targeted for the most efficacious outcome. Also, studying the effects of each sigma subtypes will aid with developing side-effect profiles of potential pharmacological compounds.

\section{Sigma Receptors and Cocaine}

Cocaine has a micromolar binding affinity for sigma receptors and, as aforementioned, this interaction of sigma and cocaine at physiologically relevant concentrations laid the groundwork for research involving the receptors as targets for putative cocaine abuse pharmacotherapies (Sharkey et al., 1988). To block or attenuate the effects of cocaine, a sigma receptor antagonist is needed (with sigma receptor agonists would exacerbate or potentiate the effects) (Matsumoto, 2003).

Many studies looking at the involvement of sigma-1 receptors in cocaine effects have been conducted. Sigma-1 receptor antagonists have been shown to significantly decrease cocaine-induced convulsions and locomotor hyperactivity in animals (Robson et al., 2011). Furthermore, many of these antagonists were even able to reduce lethality from cocaine overdose in animals (Matsumoto et al., 2003). The involvement of sigma-1 receptors in these effects was validated using antisense oligonucleotides, which reduced the number of sigma-1 receptors by 40\% (Matsumoto et al., 2003). This decrease also resulted in attenuation of cocaine-induced convulsions and hyperactivity (Matsumoto et al., 2002). Therefore, sigma-1 antagonists may serve as promising agents in pharmacotherapies for cocaine toxicity. The effect of sigma-1 in the rewarding properties of cocaine has also been evaluated. Conditioned place preference is a behavioral paradigm that measures the rewarding effects of cocaine from the ideology that animals will return and spend more time in environments in which they receive cocaine (Maurice et al., 2002). Administrations of sigma-1 antagonists have shown to attenuate cocaineinduced place preference (Romieu et al., 2000). Thus, in addition to toxicity, sigma-1 antagonists may also serve as potential pharmacological treatments for cocaine's rewarding actions.

There is a lack of molecular biological tools for evaluating sigma- 2 receptors, less is known about the role of this subtype in the effects of cocaine. Similar to sigma-1 antagonists, it has also been observed that sigma-2 receptor antagonists significantly attenuate cocaine-induced convulsions and hyperactivity (Matsumoto et al., 2007). Though the precise mechanism of sigma- 2 in cocaine-induced hyperactivity remains unclear; it is thought that the receptor modulates dopaminergic systems involved in cocaine's locomotor actions (Bastianetto et al., 1995). This ideology is largely based on the preference of DTG to act on dopaminergic systems in the nigro-striatal pathway. Additionally, a strong correlation between circling behavior and a ligand's affinity for sigma-2 receptors has been reported (Walker et al., 1993). Yet, the relatively low selectivity of these ligands used for sigma-2 versus sigma-1 and no methods for knockdown or knockout specifically for sigma-2, causes uncertainty in whether effects on cocaine behaviors is due to the specific involvement of sigma-2 receptors. 


\section{Sigma-2 Receptor Ligands}

One of the issues in studying the role of sigma-2 receptors is the paucity of selective pharmacological ligands. Functionality of ligands was characterized using the pharmacological terms for an agonist and antagonist. An agonist is a ligand causing a response at the receptor, while an antagonist inhibits the effects caused by an agonist yet has no effect alone. Previous literature has reported the development of purposed sigma-2 selective ligands. Two of these compounds that have been studied in regards to cocaine effects are sigma-2 antagonists ( \pm )-SM21 (3alpha-tropanyl-2-(4-chorophenoxy)butyrate) and UMB24 (1-(2-phenethyl)-4-(2-pyridyl)-piperazine). Though these compounds bound to sigma-2 receptors, they displayed a low selectivity, $<50$-fold, and affinity for sigma-2 receptors versus sigma-1 receptors (Matsumoto et al., 2007). Previously identified selective sigma-2 putative agonists, CB-64 ((+)-1R,5R-(E)-8-benzylidene-5-(3hydroxyphenyl)-2-methylmorphan-7- one) and CB-184 ((+)-1R,5R-(E)-8-(3,4dichlorobenzylidene)-5-(3-hydroxyphenyl)-2-methylmorphan-7 - one), displayed high selectivity, $>100$-fold and $>500$-fold respectively, yet showed only moderate binding affinity for sigma-2 receptors and exhibited binding to opioid receptors (Bowen et al., 1995; Newman and Coop, 2007). Few sigma-2 selective compounds, like RHM-4 ( $N$-(4(6,7-Dimethoxy-3,4-dihydroisoquinolin-2(1H)-yl)butyl)-2-(2-fluoroethoxy)-5-iodo-3methoxybenzamide) and WC-59 (9-(4-(2-fluoroethyl)benzyl)-9-azabicyclo[3.3.1]nonan3-yl-2-methoxy-5-methyl-phenylcarbamate), have exhibited substantial selectivity, $>1000$-fold, for sigma-2 over sigma-1 receptors (Tu et al., 2007; Chu et al., 2007). Yet, no data exhibiting their affinities for non-sigma receptor sites have been published, causing question as to whether these compounds' effects are a result of binding to sigma2 receptors. Thus, the importance of using compounds that have high binding affinity as well as high selectivity for sigma-2 versus sigma-1 receptors and non-sigma receptor sites when studying the subtype is imperative.

Our study utilized SAR assessments to synthesize a series of compounds in the hopes of identifying selective sigma-2 receptor ligands. All of the novel compounds were benzimidazolinone derivatives. This rationale was based on their preferential affinity and selectivity for sigma-2 receptors as compared to benzoxazolones (Mesangeau et al., 2008). The compounds also all contained a four-methylene spacer that proved to maximize sigma-2 versus sigma-1 receptor selectivity (Berardi et al., 2004). To further identify changes in ligand receptor affinity, three positions were substituted, $R^{1}, R^{2}$ and $\mathrm{R}^{3}$, amongst the derivatives. $\mathrm{R}^{1}$ consisted of various cyclohexylpiperazine moieties hypothesized to be a contributing factor to sigma-2 receptor selectivity. Substitutions in the $\mathrm{R}^{2}$ and $\mathrm{R}^{3}$ position primarily evaluated the effects of lipophilicity on selectivity (Mesangeau et al., 2008) (Fig. 1). Radioligand binding studies on the novel compounds determined selective, $>100$-fold, sigma- 2 receptors ligands that were then used in subsequent studies. 


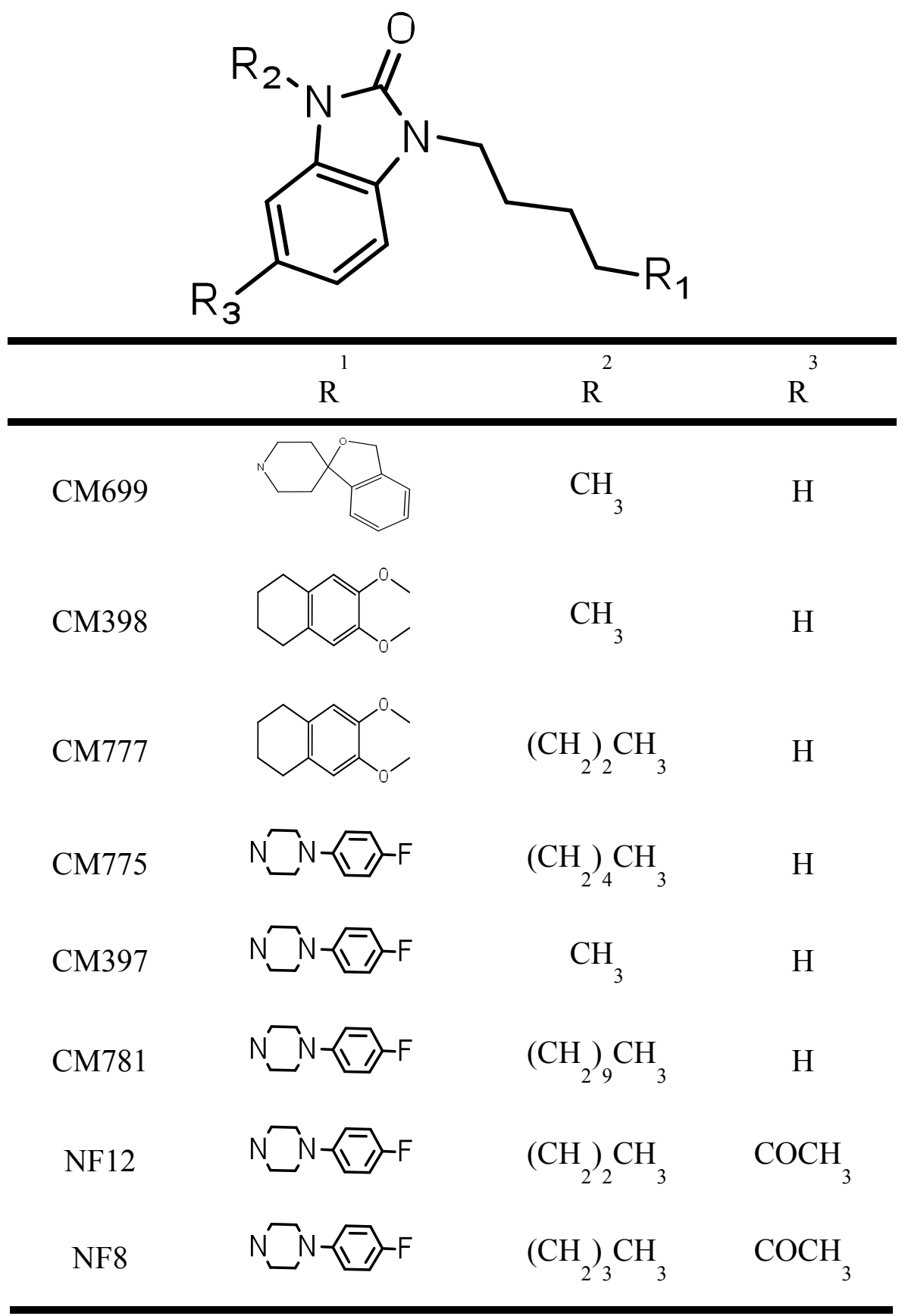

Fig. 1. Functional Group Substitutions

Different functional groups were substituted at the $\mathrm{R}^{1}, \mathrm{R}^{2}$ and $\mathrm{R}^{3}$ positions in order to evaluate the effects on sigma- 2 receptor affinity and selectivity. 


\section{E. Statement of Problem}

Sigma receptors serve as a promising target in the development of cocaine pharmacotherapies. Yet, a factor widely hindering this is the ambiguity of sigma-2 receptor involvement in cocaine's actions. This is largely due to a lack of sigma- 2 receptor pharmacological tools. Previous literature has reported the development of purported sigma-2 selective ligands yet various shortcomings can be seen. First being, that some of these compounds displayed a low selectivity for sigma-2 receptors versus sigma-1 receptors (Matsumoto et al., 2007b; Mesangeau et al 2008). A second problem being that even with compounds displaying high sigma-2 versus sigma-1 selectivity, only moderate binding affinities for the sigma-2 receptor was exhibited. Lastly, many of these purported sigma- 2 selective ligands lack data exhibiting their affinities for non-sigma receptor sites thus causing question as to whether these compounds' effects are in fact due to specific sigma-2 receptor binding (Tu et al., 2007; Chu et al., 2007). Thus, it is imperative to synthesize compounds that are both highly selective for sigma- 2 receptors versus sigma-1 and non-sigma receptors in addition to having high affinity for the receptor subtype itself in order to elucidate the receptors' effect in cocaine actions.

\section{F. Specific Aims}

\section{To determine the sigma-2 receptor affinity and selectivity of novel sigma receptor compounds.}

Sigma receptor binding affinities, of the novel sigma-2 ligands and reference compounds, will be established from brain tissue as well as liver tissue. The values will also be correlated to one another. This will be beneficial for multiple reasons:

i. Allows determination of the novel sigma-2 ligands' binding affinities for sigma and non-sigma receptors

ii. Enables comparison of the novel sigma-2 ligands binding affinities across organ tissue: Sigma-2 receptors reside in lipid rafts (Gebreselassi, 2004). Previous studies demonstrated that due to sigma-2 receptor localization in lipid rafts, binding affinity of ligands for sigma-2 could be influenced (Fishback, 2011). This is hypothesized to be a result of variations in lipid compositions and associated proteins in different lipid rafts interfering with compounds' ability to bind to the receptor (Fishback, 2011). Therefore, using both brain and liver membrane will allow comparison of sigma-2 receptor affinity ratios. If the ratio is maintained across tissue, selectivity of the compounds' for sigma- 2 receptors can more confidently be concluded.

iii. Provides similar molecular environment for comparing sigma-1 and -2 receptors: Due to brain tissue having lower concentrations of sigma- 2 than sigma1 receptors the common practice is to use liver membrane when studying the sigma-2 subtype. Since high concentrations of sigma-1 receptors are also seen in liver (Matsumoto, 2007), this tissue can be used when studying either subtypes, decreasing the likelihood data generated is an artifact of different tissues being used. 


\title{
2. To determine the effects of novel sigma-2 receptor ligands in cocaine-induced actions.
}

i. Cocaine-induced Convulsion Studies: The effects of the novel ligands on acute cocaine toxicity will be measured through the cocaine-induced convulsion behavioral paradigm. The data from this study has potential clinical significance with regards to cocaine overdose in humans.

Furthermore, this study provides a quick and easy initial screening to observe functionality of the novel ligands. An antagonist will block, while an agonist will elicit, cocaine-induced convulsions. Previous literature has shown sigma receptor antagonists to attenuate cocaine-induced convulsions (Katz et al., 2011).

Conversely, sigma receptor agonists have shown to cause convulsions at low doses of cocaine that administered alone show no convulsive effects (Katz et al., 2011). Additionally, sigma agonists worsened cocaine toxicity by causing lethality in response to doses of cocaine that given alone are not lethal (Matsumoto et al., 2003). These agonistic outcomes produced a leftward shift in cocaine-induced convulsion dose response curves (Matsumoto et al., 2002).

ii. Locomotor Activity Studies: The impact of the novel ligands on cocaine psychomotor stimulant effects will be measured with locomotor activity behavioral tests. This paradigm reflects the stimulant actions seen in persons upon the administration of cocaine. These stimulant actions contribute to the drug's rewarding properties. Thus, locomotor activity will provide additional information for the sigma receptor compounds being putative cocaine pharmacotherapies.

Locomotor activity studies will provide an easy and fairly quick initial screen of ligand functionality which can subsequently help choose compounds to include in more time consuming and intricate cocaine behavioral tests (Matsumoto et al., 2007). Earlier studies have characterized sigma antagonists blocking and agonists exacerbating, cocaine-induced locomotor hyperactivity (Katz et al., 2011).

\section{MATERIALS AND METHODS}

\author{
A. Drugs and Chemicals \\ CM398 (1-(4-(6,7-dimethoxy-3,4-dihydroisoquinolin-2(1H)-yl)butyl)-3-methyl-1H - \\ benzo[ $d$ ] imidazol-2(3H)-one), CM699 (1-(4-(3H-spiro[isobenzofuran-1,4'-piperidin]-1'- \\ yl)butyl)-3-methyl-1H -benzo[ $d]$ imidazol-2(3H)-one), CM77 (1-(4-(4-(4- \\ flurophenyl)piperazin-1-yl)butyl)-3-pentyl-1 $H$-benzo[ $d]$ imidazol-2(3H)-one) and \\ CM775 (1-(4-(4-(4-flurophenyl)piperazin-1-yl)butyl)-3-propyl-1 $H$-benzo[ $d]$ imidazol- \\ $2(3 H)$-one) were synthesized at the University of Mississippi (University, MS). The \\ structures of these novel ligands are shown in Fig. 2. Cocaine hydrochloride was obtained \\ from Sigma-Aldrich (St. Louis, MO). The radioligands were procured from Perkin Elmer \\ (Boston, MA) and all other chemicals used were obtained from standard commercial \\ suppliers (Sigma-Aldrich, Milwaukee, WI).
}


Solutions of the compounds' tested in radioligand binding assays were prepared by diluting with deionized water or DMSO, depending on the compounds' solubility properties. While, the receptors were labeled with radioligand solutions prepared with 50 $\mathrm{nM}$ Tris buffer. In the behavioral studies using mice, all of the compound and drug preparations were diluted using saline
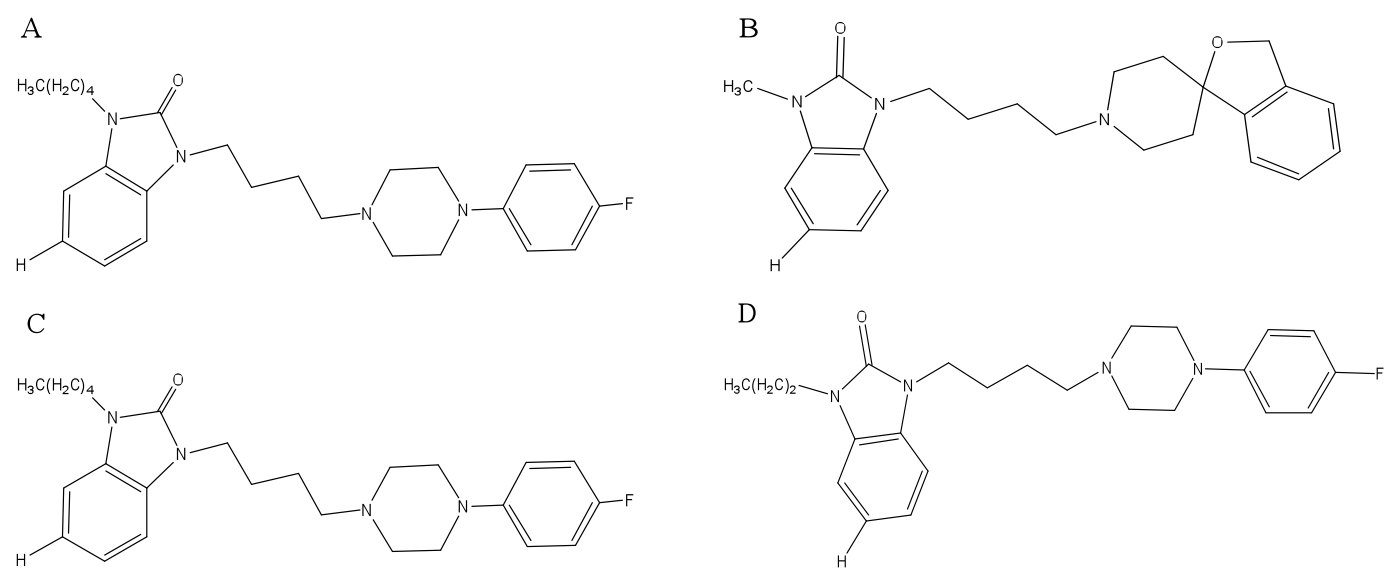

Fig. 2. Chemical structures of novel ligands.

A, CM398 (1-(4-(6,7-dimethoxy-3,4-dihydroisoquinolin-2(1H)-yl)butyl)-3-methyl-1Hbenzo[ $d$ ]imidazol-2(3H)-one), B, CM699 (1-(4-(3H-spiro[isobenzofuran-1,4'-piperidin]1'-yl)butyl)-3-methyl-1H-benzo[d]imidazol-2(3H)-one), C, CM775 (1-(4-(4-(4flurophenyl)piperazin-1-yl)butyl)-3-pentyl-1 $H$-benzo[ $d]$ imidazol-2(3H)-one) and $\mathrm{D}$, CM777 (1-(4-(4-(4-flurophenyl)piperazin-1-yl)butyl)-3-propyl-1H-benzo[ $d$ ]imidazol$2(3 H)$-one).

\section{B. Animals}

Male, Swiss Webster mice (22-36 g; Harlan, Indianapolis, IN) were housed in groups of five in a 12:12-h light/dark cycle with food and water ad libitum. Naïve mice were randomly assigned to various treatment groups. All procedures using animals were performed as approved by the IACUC at West Virginia University.

\section{Radioligand Binding Assays}

Membrane Preparation

Rat brain $\mathrm{P}_{2}$ and rat liver $\mathrm{P}_{2}$ fractions were made from male, Sprague Dawley rats (150$200 \mathrm{~g}$; Harlan, Indianapolis, IN). In accordance with IACUC, rats were selected, instead of mice, in order to use the fewest number of animals without compromising the integrity of the data. In brief, the animals were first decapitated and the brain minus the cerebellum were collected and put in ice-cold $10 \mathrm{mM}$ Tris $/ 0.9 \% \mathrm{NaCl}$ buffer. The tissue is homogenized in ice-cold in $10 \mathrm{mM}$ Tris-sucrose buffer $(0.32 \mathrm{M}$ sucrose in $10 \mathrm{mM}$ Tris, $\mathrm{pH}$ 7.4) with a Potter-Elvehjem homogenizer (5-10 strokes with motor driven Teflon pestle) using $10 \mathrm{~mL}$ buffer per gram of wet tissue with about 3 grams of tissue per batch. The homogenates were then centrifuged at $1000 \mathrm{xg}$ at $4^{\circ} \mathrm{C}$ for $10 \mathrm{~min}$ and the supernatants were then taken and centrifuged again at $31,000 \mathrm{x} \mathrm{g}$ at $4^{\circ} \mathrm{C}$ for $15 \mathrm{~min}$. The pellets from this centrifugation were resuspended in $3 \mathrm{~mL}$ of $10 \mathrm{mM}$ Tris ( $\mathrm{pH}$ 7.4) per every gram of tissue. The homogenates were then incubated at $25^{\circ} \mathrm{C}$ for $30 \mathrm{~min}$ and then 
centrifuged at $31,000 \mathrm{x} \mathrm{g}$ at $4^{\circ} \mathrm{C}$ for $15 \mathrm{~min}$. The resulting pellets were resuspended in 10 $\mathrm{mM}(\mathrm{pH}$ 7.4) to achieve a final concentration of 1 gram of tissue per $1.53 \mathrm{~mL}$ of buffer. The homogenates were stored at $-80^{\circ} \mathrm{C}$ in $1 \mathrm{~mL}$ aliquots. Protein concentrations were determined using The Better Bradford Assay Kit (Pierce, Rockford, IL).

Sigma Receptor Binding Assays

The binding affinities of tested compounds for sigma receptors were determined using two competition binding assay methods. The primary difference between the methods is tissue type, rat brain $\mathrm{P}_{2}$ membrane was used in the conventional Brandel-method and rat liver $\mathrm{P}_{2}$ membrane was used in the 96-well plate method. Stock solutions of the ligands were prepared in deionized water or DMSO. Each compound tested was assayed at 10-12 concentrations to determine binding affinities. Sigma-1 receptors were labeled with $5 \mathrm{nM}$ $\left[{ }^{3} \mathrm{H}\right](+)$-pentazocine; sigma-2 receptors were labeled with $3 \mathrm{nM}\left[{ }^{3} \mathrm{H}\right]$ DTG in the presence of $300 \mathrm{nM}(+)$-pentazocine. Nonspecific binding was determined using $10 \mu \mathrm{M}$

haloperidol. The assays were incubated for $120 \mathrm{~min}$ at $25^{\circ} \mathrm{C}$. Prior to use, filters were soaked in $0.5 \% \mathrm{PEI}$, to decrease non-specific binding, for $30 \mathrm{~min}$. After incubation, assay solutions were filtered with respective harvesters based on the aforementioned methods and washed three times with ice-cold $10 \mathrm{mM}$ Tris buffer. Counts were extracted from the filters with the addition of scintillation cocktail. All competition binding assays on test ligands had a minimum of three trials completed with each trial being run in duplicates.

In addition to the novel sigma-2 ligands, reference compounds (haloperidol, DTG, AC927, (+)-pentazocine, and (-)-pentazocine) were tested using the 96-well plate assay. These compounds were chosen because they are previously profiled sigma ligands with well-characterized pharmacological properties (Fishback, 2011).

\section{Non-Sigma Receptor Binding Assays}

The selectivity for the following monoamine transporters were choose because of cocaine's known interactions with them. Dopamine transporters were labeled with $\left[{ }^{3} \mathrm{H}\right]$ WIN 35,428 and nonspecific binding was determined using $50 \mu \mathrm{M}$ cocaine in rat striatal tissue. Serotonin transporters were labeled with $\left[{ }^{3} \mathrm{H}\right]$ paroxetine with nonspecific binding determined using $1.5 \mu \mathrm{M}$ imipramine in rat brainstem tissue. Lastly, norepinephrine transporters were labeled with $\left[{ }^{3} \mathrm{H}\right]$ nisoxetine and nonspecific binding was determined with $4 \mu \mathrm{M}$ desipramine in rat cerebral cortical tissue.

Previously established sigma ligands showed to interact with various non-sigma sites, therefore, the selectivity of the sigma-2 ligands for dopamine $\left(\mathrm{D}_{2}\right)$, and serotonin $\left(5-\mathrm{HT}_{2}\right)$ receptors were determined in rat brain without cerebellum homogenate (Guitart et al., 2004). While opioid (mu, kappa, delta) receptor binding affinities were determined in $\mathrm{CHO}$ cells transected with human mu (hMOR), kappa (hKOR) and delta (hDOR). NMDA receptors were labeled with $5 \mathrm{nM}\left[{ }^{3} \mathrm{H}\right] \mathrm{TCP}$ with nonspecific binding determined with $10 \mu \mathrm{M}$ cyclazocine. Dopamine receptors were labeled with $5 \mathrm{nM}\left[{ }^{3} \mathrm{H}\right](-)$ sulpiride and nonspecific binding was established using $1 \mu \mathrm{M}$ haloperidol. Furthermore, serotonin receptors were labeled with $2 \mathrm{nM}\left[{ }^{3} \mathrm{H}\right]$ ketanserin and nonspecific binding was found

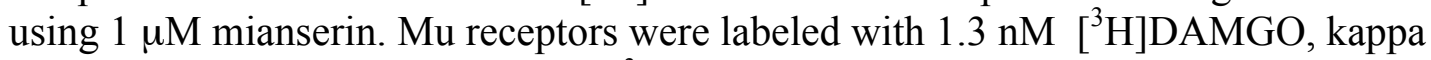
receptors were labeled with $1.7 \mathrm{nM}\left[{ }^{3} \mathrm{H}\right] \mathrm{U} 69,593$ and delta receptors with $1.2 \mathrm{nM}$ 
$\left[{ }^{3} \mathrm{H}\right]$ DPDPE. Nonspecific binding for the opioid receptor subtypes was determined using $1 \mu \mathrm{M}$ DAMGO (mu), $1 \mu \mathrm{M}$ U69,593 (kappa) and DPDPE (delta). Incubation time was $60 \mathrm{~min}$ at $25^{\circ} \mathrm{C}$ for dopamine and opioid receptor assays. For serotonin receptors, the assays were incubated for $30 \mathrm{~min}$ at $37^{\circ} \mathrm{C}$ and $60 \mathrm{~min}$ at $4^{\circ} \mathrm{C}$ for NMDA receptor assays.

After incubation, assay solutions were filtered and washed three times with ice-cold 10 $\mathrm{mM}$ Tris buffer. Counts were extracted from the filters with the addition of scintillation cocktail.

\section{Cocaine-induced Convulsions}

This study was conducted in order to observe the novel sigma-2 ligands' effects on acute cocaine toxicity. Attenuation of the convulsions is expected from putative antagonists while elicitation of cocaine-induced convulsions and/or lethality is expected from putative agonists.

\section{Cocaine Dose Response}

To find a convulsive dose of cocaine, animals $(n=50)$ were given a pretreatment of saline followed 15 min later with administration of a varying dose of cocaine (40-70 $\mathrm{mg} / \mathrm{kg}$, i.p.) The doses of cocaine chosen for the dose response were based on previous studies (Xu et al., 2010). The animals were then placed in individual plastic chambers (59 x $43 \times 13 \mathrm{~cm}$ ) and observed for the occurrence of convulsions over a $30 \mathrm{~min}$ time period. Convulsions were operationally defined as a loss of righting reflex for at least $5 \mathrm{~s}$ accompanied by clonic or tonic limb movements and/or popcorn jumping. The number of animals displaying convulsions was recorded in each experimental group.

\section{Testing for Antagonist and Agonist Effects}

First, to observe anticonvulsant effects against cocaine, the animals $(n=125)$ were given a $15 \mathrm{~min}$ pretreatment of a sigma-2 ligand $(0.1-20 \mathrm{mg} / \mathrm{kg}$ i.p.) followed by a convulsive dose of cocaine $(70 \mathrm{mg} / \mathrm{kg}$, i.p.) which produced $100 \%$ convulsions without lethality. Next, CM699 was probed for agonist effects based on the observation of lethality with pretreatment to the $70 \mathrm{mg} / \mathrm{kg}$ (i.p.) convulsive dose of cocaine. Here, the challenge dose of cocaine was varied ( $40-70 \mathrm{mg} / \mathrm{kg}$, i.p.) in order to observe exacerbation of convulsions leading to a leftward shift in the cocaine dose-response. After administration of the dosing regimen, the animals were then placed in individual plastic chambers $(59 \mathrm{x} 43 \mathrm{x}$ $13 \mathrm{~cm}$ ) and observed for the occurrence of convulsions over a $30 \mathrm{~min}$ time period. Convulsions were operationally defined as a loss of righting reflex for at least $5 \mathrm{~s}$ accompanied by clonic or tonic limb movements and/or popcorn jumping. The number of animals displaying convulsions was recorded in each experimental group.

\section{E. Locomotor Activity}

This study was performed in order to observe the novel sigma-2 ligands' effects on cocaine psychomotor stimulant effects. Attenuation of cocaine-induced locomotor hyperactivity and no effect on basal locomotor activity is expected from putative antagonists while exacerbation is expected from putative agonists. 


\section{Cocaine Dose Response}

The mice were first acclimated to the testing room for $30 \mathrm{~min}$ and then individually to the Plexiglas testing chambers of the automated activity monitoring system for $30 \mathrm{~min}$ (San Diego Instruments, San Diego, CA). To find a locomotor stimulant dose of cocaine, animals $(n=38)$ were administered varying doses of cocaine $(0-30 \mathrm{mg} / \mathrm{kg}$, i.p. $)$, used in previous studies, to determine a dose response curve (McCracken et al., 1999). Total locomotor activity (ambulatory, fine, and rearing movements) was quantified as the number of disruptions in the $16 \times 16$ photobeam grid in the Plexiglas testing chambers. The dose of cocaine that produced the highest level of locomotor hyperactivity was used in the subsequent locomotor experiments.

\section{Testing for Antagonist and Agonist Effects}

The mice were first acclimated to the testing room for $30 \mathrm{~min}$ and then individually to the Plexiglas testing chambers of the automated activity monitoring system for $30 \mathrm{~min}$ (San Diego Instruments, San Diego, CA). To measure the effects of the sigma-2 ligands alone and on cocaine-induced locomotor hyperactivity, the mice $(n=144)$ were administered (i.p.) a $15 \mathrm{~min}$ pretreatment of a sigma-2 compound (0.1-20 mg/kg, i.p.) followed by a locomotor stimulatory challenge dose of cocaine $(30 \mathrm{mg} / \mathrm{kg}$, i.p.; $n=78)$ or saline $(n=$ 66). Starting ligand pretreatment doses were determined by taking effective doses used in the convulsion studies, into consideration. While the stimulant dose of cocaine produced the highest level of locomotor hyperactivity.

\section{F. Data Analysis}

All data were analyzed using GraphPad Prism (GraphPad Software Inc., San Diego, CA). The data from the binding assays were analyzed using a non-linear regression (curve fit) using the Cheng-Prusoff equation and $\mathrm{K}_{d}$ values were determined in separate saturation assays. The data from the convulsion studies were analyzed using Fisher's exact tests. The data from the locomotor activity studies were analyzed using a one-way analysis of variance (ANOVA) followed by post-hoc Dunnett's, for comparison to controls, or Tukey's, for pairwise comparisons, tests. Values of $p<0.05$ were considered statistically significant. 


\section{RESULTS}

\section{A. Sigma and Non-sigma Receptor Binding Affinities}

Table 1 summarizes the affinities of CM699, CM398, CM777 and CM775 for sigma-1 and sigma-2 receptors, as well as seven other receptors and transporters in brain homogenate. All compounds displayed subnanomolar affinities for sigma-2 receptors and moderate to low affinity for sigma-1 receptors. Specifically, CM699, CM398 and CM777 all had $>1000$-fold preference for sigma- 2 receptors versus sigma-1 receptors and CM775 possessed a $>500$-fold preference for sigma- 2 receptors.

All of the compounds maintained selectivity for sigma-2 receptors versus the non-sigma sites tested. CM699 and CM398 displayed a >1000-fold and $>50$-fold preference, respectively, for sigma-2 receptors over DAT. Furthermore, CM398 and CM775 both showed $>100$-fold affinity for sigma-2 receptors versus SERT. CM777 and CM775 had $>50$-fold selectivity for sigma- 2 over $5-\mathrm{HT}_{2}$ receptors. All other binding affinities of the novel compounds to non-sigma sites were negligible. Compared to their high affinity for sigma-2 receptors, CM699, CM398 and CM777 all displayed 500-fold weaker affinity for non-sigma sites tested.

\begin{tabular}{|c|c|c|c|c|c|c|c|c|c|}
\hline \multicolumn{3}{|c|}{$\begin{array}{c}\text { Sigma receptors } \\
\mathrm{K}_{\mathrm{i}}(\mathrm{nM})\end{array}$} & \multicolumn{3}{|c|}{$\begin{array}{l}\text { Monoamine transporters } \\
\mathrm{K}_{\mathrm{i}}(\mathrm{nM})\end{array}$} & \multicolumn{4}{|c|}{$\begin{array}{l}\text { Other neurotransmitter receptors } \\
\qquad \mathrm{K}_{\mathrm{i}}(\mathrm{nM})\end{array}$} \\
\hline & $\sigma_{1}$ & $\sigma_{2}$ & DAT & SERT & NET & $\mathrm{D}_{2}$ & $5-\mathrm{HT}_{2}$ & NMDA & Opioid \\
\hline CM699 & $\begin{array}{c}16.7 \\
\pm 1.09\end{array}$ & $\begin{array}{c}0.01 \\
\pm 0.00\end{array}$ & $\begin{array}{l}131.5 \\
\pm 1.9\end{array}$ & $>1000$ & $>1000$ & $>1000$ & $>1000$ & $>10000$ & $>1000$ \\
\hline CM398 & $\begin{array}{c}560 \\
\pm 8.72\end{array}$ & $\begin{array}{c}0.43 \\
\pm 0.02\end{array}$ & $\begin{array}{r}32.9 \\
\pm 1.9\end{array}$ & $\begin{array}{l}244.2 \\
\pm 2.4\end{array}$ & $>1000$ & $>1000$ & $>1000$ & $>10000$ & $>1000$ \\
\hline CM777 & $\begin{array}{c}752 \\
\pm 51.4\end{array}$ & $\begin{array}{c}0.66 \\
\pm 0.01\end{array}$ & $>1000$ & $>1000$ & $>10000$ & $>10000$ & $\begin{array}{c}54.7 \\
\pm 0.27\end{array}$ & $>10000$ & $>10000$ \\
\hline CM775 & $\begin{array}{l}2270 \\
\pm 187\end{array}$ & $\begin{array}{c}4.3 \\
\pm 0.29\end{array}$ & $>1000$ & $\begin{array}{l}445.9 \\
\pm 3.2\end{array}$ & $>10000$ & $>1000$ & $\begin{array}{l}249.6 \\
\pm 4.8\end{array}$ & $>10000$ & $>10000$ \\
\hline
\end{tabular}

Table 1. Binding affinities of CM699, CM398, CM777 and CM775.

Affinities ( $\mathrm{K}_{\mathrm{i}}$ values in nanomolar) were determined in brain tissue homogenates with the exception of opioid receptors in $\mathrm{CHO}$ cells. The values represent \pm S.E.M. from replicate assays. Values of $>10,000$ represent less than $30 \%$ displacement of the radioligand at that concentration.

To determine the correlation between binding affinities of our novel compounds in addition to the reference compounds tested in brain versus liver tissue, a correlation analysis was performed (Fig. 2). Table 2 summarizes the affinities of CM699, CM398, CM775 and five sigma receptor reference compounds (haloperidol, DTG, AC927, (+)pentazocine, and (-)-pentazocine) at sigma-1 and sigma-2 receptors in liver tissue homogenate. CM777 was not tested. At both sigma-1 and sigma-2 receptors, a significant correlation was reported between brain and liver homogenate $\left(r^{2}=0.99\right.$ and $r^{2}=0.99$, respectively). 


\begin{tabular}{ccccccc}
\hline & \multicolumn{3}{c}{ Liver Tissue } & \multicolumn{3}{c}{ Brain Tissue } \\
& $\sigma_{1}$ & $\sigma_{2}$ & $\sigma_{1} / \sigma_{2}$ & $\sigma_{1}$ & $\sigma_{2}$ & $\sigma_{1} / \sigma_{2}$ \\
& $\mathrm{~K}_{\mathrm{i}}(\mathrm{nM})$ & $\mathrm{K}_{\mathrm{i}}(\mathrm{nM})$ & & $\mathrm{K}_{\mathrm{i}}(\mathrm{nM})$ & $\mathrm{K}_{\mathrm{i}}(\mathrm{nM})$ & \\
\hline \multirow{2}{*}{ Haloperidol } & 3.8 & 114.0 & .03 & $3.9^{\mathrm{a}}$ & $155 \mathrm{a}$ & .03 \\
& \pm 0.5 & \pm 7.0 & & \pm 0.5 & \pm 2.0 & \\
DTG & 28.2 & 20.2 & \multirow{2}{*}{1.4} & $57.4 \mathrm{a}$ & $43.3 \mathrm{a}$ & 1.3 \\
& \pm 4.0 & \pm 6.4 & & \pm 3.3 & \pm 0.6 & \\
AC927 & 44.4 & 106.7 & .41 & $61.2^{\mathrm{a}}$ & $384^{\mathrm{a}}$ & .16 \\
& \pm 4.8 & \pm 6.4 & & \pm 5.6 & \pm 34.0 & \\
$(+)-$-Pentazocine & 8.0 & 1419.0 & .01 & $8.65^{\mathrm{a}}$ & $1414^{\mathrm{a}}$ & .01 \\
& \pm 0.4 & \pm 65.3 & & \pm 0.4 & \pm 207 & \\
$(-)$-Pentazocine & 11.5 & 28.1 & .41 & $57.2^{\mathrm{a}}$ & $108^{\mathrm{a}}$ & .53 \\
& \pm 2.2 & \pm 1.5 & & \pm 1.9 & \pm 4.40 & \\
CM699 & 21.7 & 1.6 & \multirow{2}{*}{14} & 16.7 & 0.01 & 1700 \\
& \pm 3.5 & \pm 0.3 & & \pm 1.09 & \pm 0.00 & \\
CM398 & 388.0 & 0.7 & 550 & 560 & 0.43 & 950 \\
& \pm 60.6 & \pm 0.2 & & \pm 8.72 & \pm 0.02 & \\
CM775 & 2561.3 & 31.0 & 82 & 2270 & 4.3 & 42 \\
& \pm 242.7 & \pm 3.5 & 82 & \pm 187 & \pm 0.29 & \\
\hline
\end{tabular}

Table 2. Binding affinities of sigma reference ligands and CM699, CM398, and CM775 in liver and brain.

Affinities ( $\mathrm{K}_{\mathrm{i}}$ values in nanomolar) were determined in liver and brain tissue homogenates. The values represent \pm S.E.M. from replicate assays.
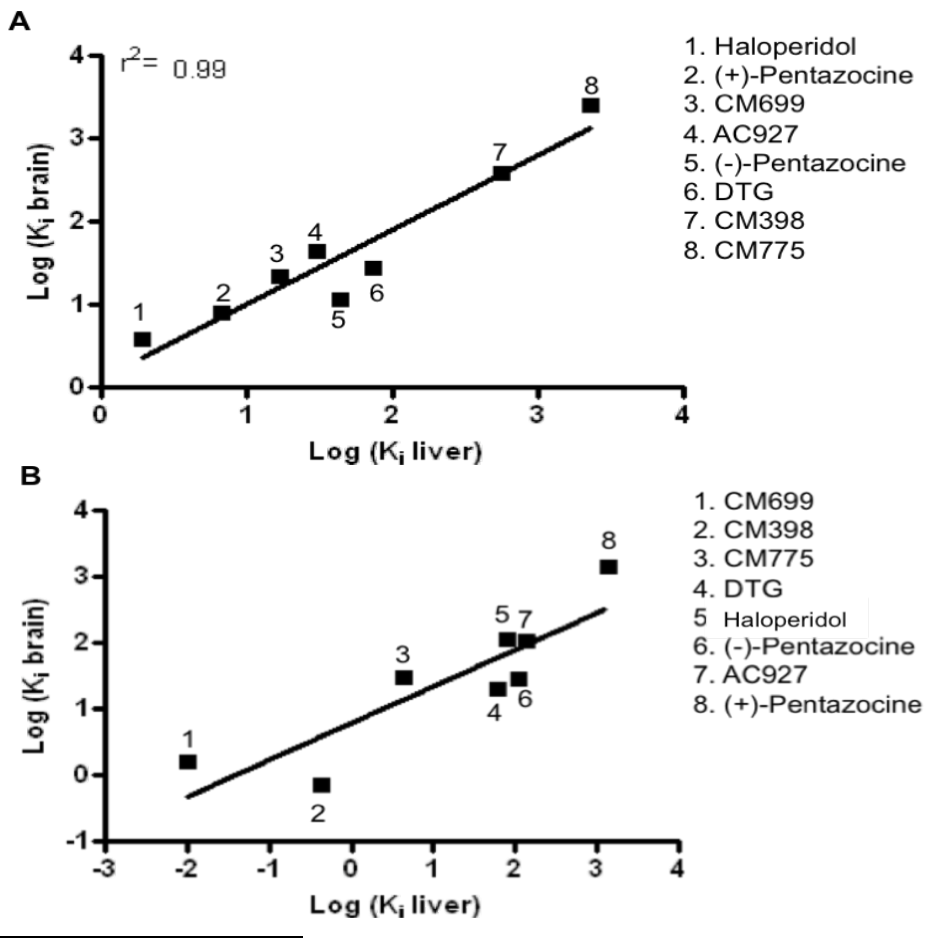

${ }^{\text {a }}$ Fishback, 2011 
Fig. 3. Correlation plot of sigma receptor binding affinities in brain and liver membrane.

A, Sigma-1 receptor radioligand binding affinities, CM699, CM398, CM775 and five reference compounds were correlated in brain and liver tissue $\left(r^{2}=0.99, p<0.0001\right)$.

B, Sigma-2 receptor radioligand binding affinities for CM699, CM398, CM775 and five reference compounds were correlated in brain and liver tissue $\left(r^{2}=0.99, p<0.001\right)$.

$\mathrm{K}_{\mathrm{i}}$ values represent means determined from a minimum of 3 assays.

\section{B. Cocaine-induced Convulsions}

Cocaine Dose Response

Cocaine elicited convulsions in a dose-dependent manner, with $100 \%$ of the animals convulsing at the dose of $70 \mathrm{mg} / \mathrm{kg}$ of cocaine (Fig. 4A). While animals administered saline alone showed $0 \%$ convulsions (data not shown). Fisher's exact test showed significantly more convulsions at $70 \mathrm{mg} / \mathrm{kg}$ of cocaine (\#\#\#p<0.001 vs. saline).

\section{Testing for Antagonist and Agonist Effects}

Convulsions, caused by a cocaine dose of $70 \mathrm{mg} / \mathrm{kg}$, were attenuated following pretreatment with CM398 (Fig. 4B; $20 \mathrm{mg} / \mathrm{kg}$, p<0.05) CM777 (Fig. 4C; $10 \mathrm{mg} / \mathrm{kg}$, $\mathrm{p}<0.001$ ), and CM775 (Fig. 4D; $20 \mathrm{mg} / \mathrm{kg}, \mathrm{p}<0.05$ ). Conversely, CM699 was unable to block the cocaine-induced convulsions. Pretreatment with CM699 $(10 \mathrm{mg} / \mathrm{kg})$ followed by $70 \mathrm{mg} / \mathrm{kg}$ of cocaine produced $100 \%$ convulsions followed by $60 \%$ lethality in the animals (data not shown). Previous studies have shown similar observations with sigma receptor agonists, leading CM699 to be probed for exacerbation of cocaine convulsions (Matsumoto et al., 2002; McCracken et al., 1999). Pretreatment with CM699 (5 mg/kg) prior to a non-convulsive dose of cocaine $(50 \mathrm{mg} / \mathrm{kg}$ ) caused convulsions in $50 \%$ of the mice (Fig. 5; p <0.01). Pretreatment with CM699 $(5 \mathrm{mg} / \mathrm{kg})$ prior to a convulsive dose of cocaine $(60 \mathrm{mg} / \mathrm{kg})$ increased the occurrence of convulsions by $50 \%$ in the mice $(\mathrm{p}<0.05)$. The $\mathrm{ED}_{50}$ for cocaine alone was $62 \mathrm{mg} / \mathrm{kg}$ while CM699 pretreatment (1 and 5 $\mathrm{mg} / \mathrm{kg}$ ) to a dose of cocaine displayed $\mathrm{ED}_{50}$ values of $55 \mathrm{mg} / \mathrm{kg}$ and $48 \mathrm{mg} / \mathrm{kg}$, respectively.
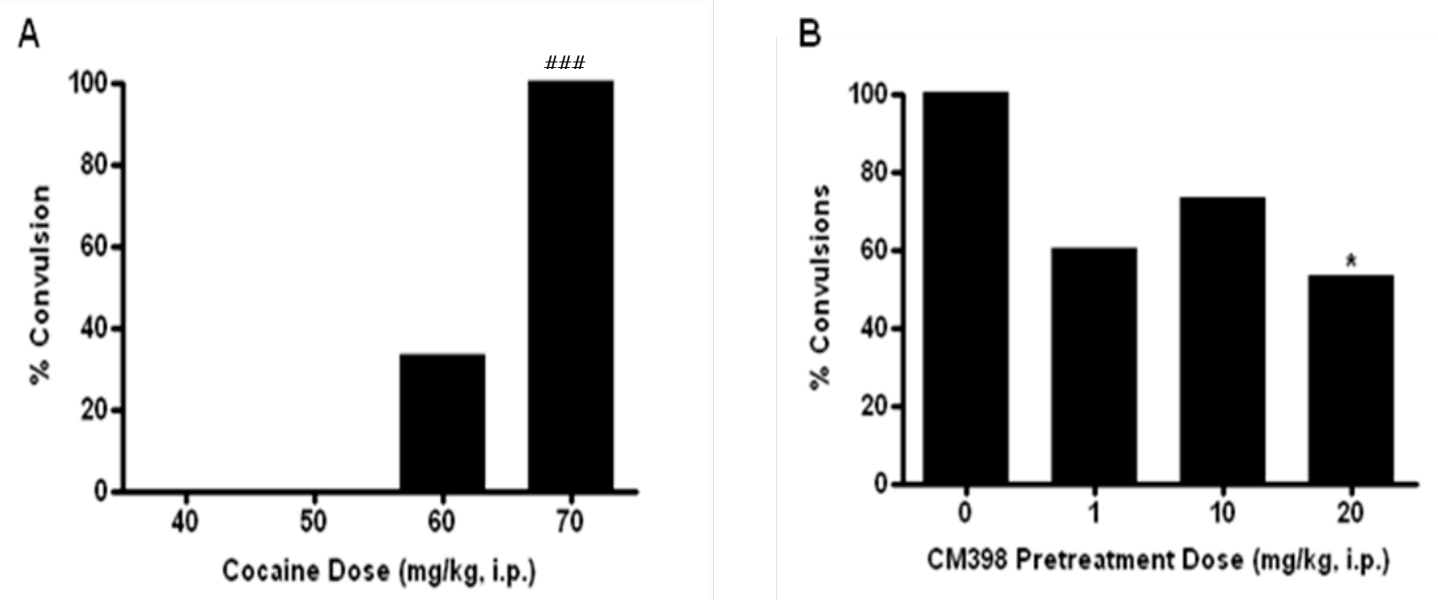
C

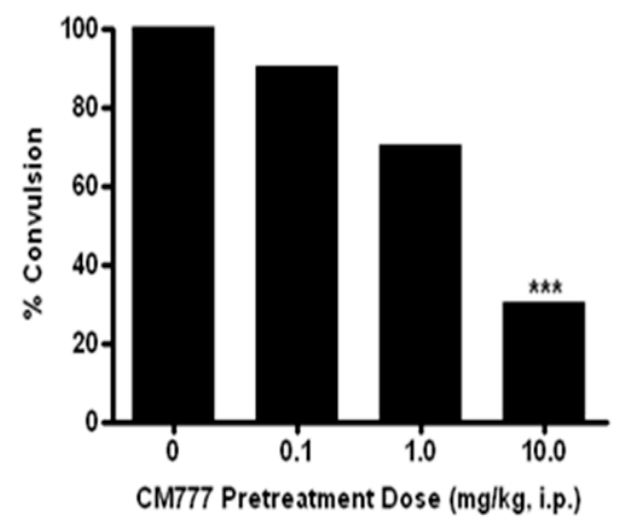

D

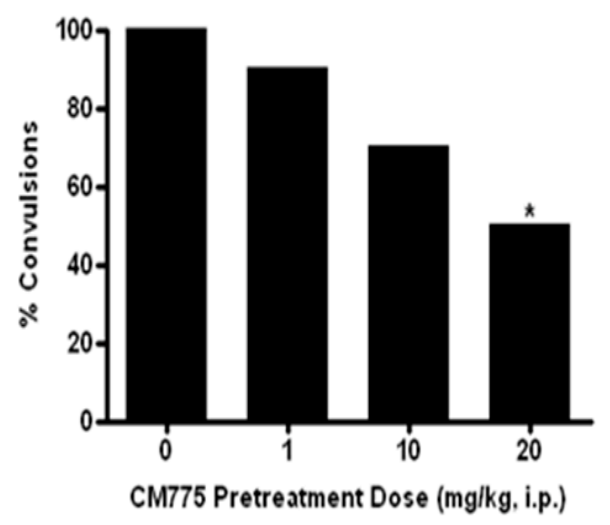

Fig. 4. The effects of cocaine, CM398, CM777, and CM775 on convulsions. Male, Swiss Webster mice were pretreated (i.p.) with saline, CM398, CM777, or CM775 prior to cocaine. A, administration of cocaine $(40-70 \mathrm{mg} / \mathrm{kg}$, i.p.) produced a dosedependent increase in the percentage of animals displaying convulsions. B, Pretreatment of CM398 (0-20 mg/kg, i.p.) prior to a convulsive dose of cocaine ( $70 \mathrm{mg} / \mathrm{kg}$, i.p.) caused a significant reduction in the occurrence of convulsions. C, Pretreatment of CM777 (0-10 $\mathrm{mg} / \mathrm{kg}$, i.p.) prior to a convulsive dose of cocaine $(70 \mathrm{mg} / \mathrm{kg}$, i.p.) caused a dosedependent decrease in the occurrence of convulsions. D, Pretreatment of CM775 (0-20 $\mathrm{mg} / \mathrm{kg}$, i.p.) prior to a convulsive dose of cocaine $(70 \mathrm{mg} / \mathrm{kg}$, i.p.) produced a dosedependent decrease in the occurrence of convulsions. \#\#\#p<0.001 vs. saline; ${ }^{*} \mathrm{p}<0.05$, *** $p<0.001$ vs. cocaine $(70 \mathrm{mg} / \mathrm{kg})$; Fisher's exact test.

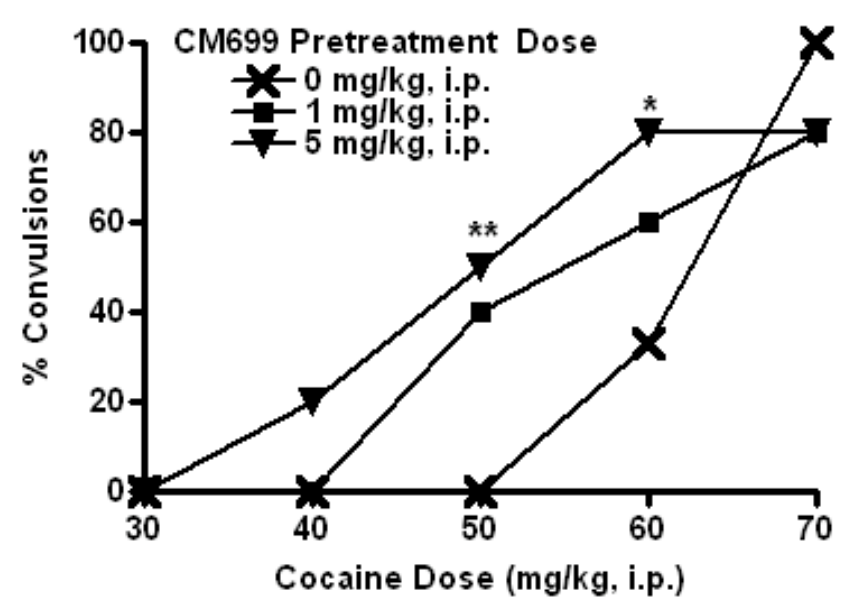

Fig. 5. The effects of cocaine and CM699 on convulsions.

Male, Swiss Webster mice administered cocaine alone (no CM699 pretreatments) showed either no or lower numbers of convulsions. Male, Swiss Webster mice pretreated (i.p.) with CM699 (5 mg/kg) prior to a non-convulsive dose of cocaine $(50 \mathrm{mg} / \mathrm{kg}$, i.p.) significantly caused $50 \%$ of the animals to convulse. While pretreatment of CM699 (5 $\mathrm{mg} / \mathrm{kg}$, i.p.) prior to a convulsive dose of cocaine $(60 \mathrm{mg} / \mathrm{kg}$, i.p.) resulted in a significant increase, from $30 \%$ to $80 \%$, of convulsions. ${ }^{*} \mathrm{p}<0.05$ vs. cocaine $(60 \mathrm{mg} / \mathrm{kg}),{ }^{* *} \mathrm{p}<0.01$ vs. cocaine $(50 \mathrm{mg} / \mathrm{kg})$; Fisher's exact test. 


\section{Locomotor Activity}

\section{Cocaine Dose Response}

Cocaine dose-dependently increased locomotor activity (Fig. 6A). One-way ANOVA showed significant differences between all groups tested $(F(3,31)=8.61, \mathrm{p}<0.001)$. Post-hoc Dunnett's test confirmed significant increases in locomotor activity at 20 and 30 $\mathrm{mg} / \mathrm{kg}(\mathrm{q}=4.72, \mathrm{p}<0.05 ; \mathrm{q}=6.45, \mathrm{p}<0.001$, respectively $)$

\section{Testing for Antagonist Effects}

Pretreatment with CM398 (Fig. 6B), CM777 (Fig. 6D) and CM775 (Fig. 6F) prior to a locomotor stimulant dose of cocaine $(30 \mathrm{mg} / \mathrm{kg})$ significantly attenuated cocaine-induced hyperactivity. One-way ANOVA showed significant differences between all groups tested for CM398, CM777 and CM775 $(F(3,36)=5.09, \mathrm{p}<0.01 ; F(3,25)=7.87, \mathrm{p}<$ $0.001 ; F(3,37)=6.36, \mathrm{p}<0.001$, respectively). Post-hoc Dunnett's multiple comparisons test confirmed a significant protective effect for each compound at the following doses: $20 \mathrm{mg} / \mathrm{kg}$ of CM398 ( $\mathrm{q}=5.42, \mathrm{p}<0.01)$ and CM777 $(\mathrm{q}=6.86, \mathrm{p}<0.001), 1 \mathrm{mg} / \mathrm{kg}$ and $10 \mathrm{mg} / \mathrm{kg}$ of CM775 (q = 4.06, $\mathrm{p}<0.05 ; \mathrm{q}=6.09, \mathrm{p}<0.001$, respectively). Each compound tested displayed no significant effects on its own at any of the doses administered: CM398 (Fig. 6C, $F(3,31)=.056$, p $>0.05$ ), CM775 (Fig. 6E, $F(3,37)=$ 2.86, $\mathrm{p}>0.05$ ) and CM777 (Fig. 6G, $F(3,23)=2.57, \mathrm{p}>0.05)$.

Since the ability of the compounds' to block stimulant locomotor hyperactivity was being examined in these experiments and CM699 displayed agonistic properties in the convulsion studies, it was excluded from these tests.

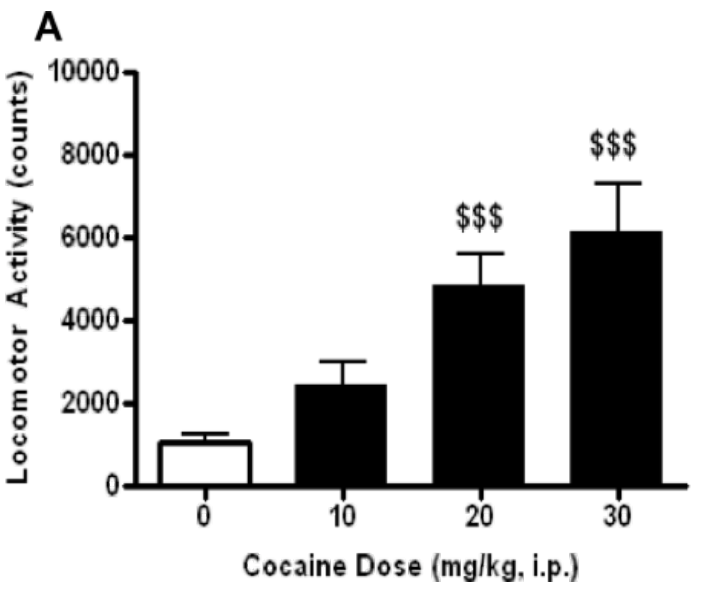

\section{B}

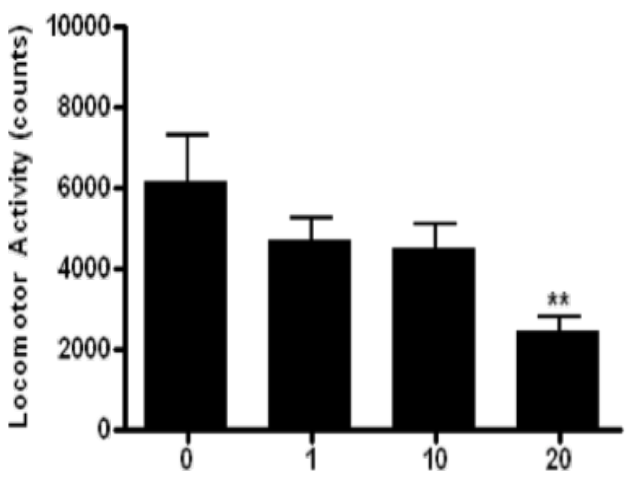

CM398 Pretreatment Dose (mg/kg, i.p.)
C

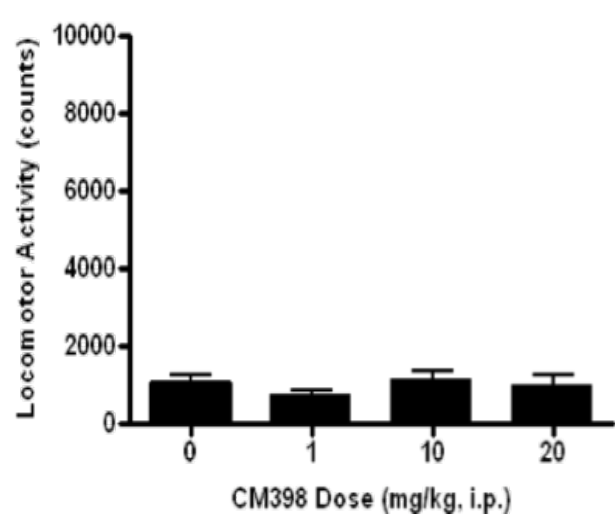


$\mathbf{F}$

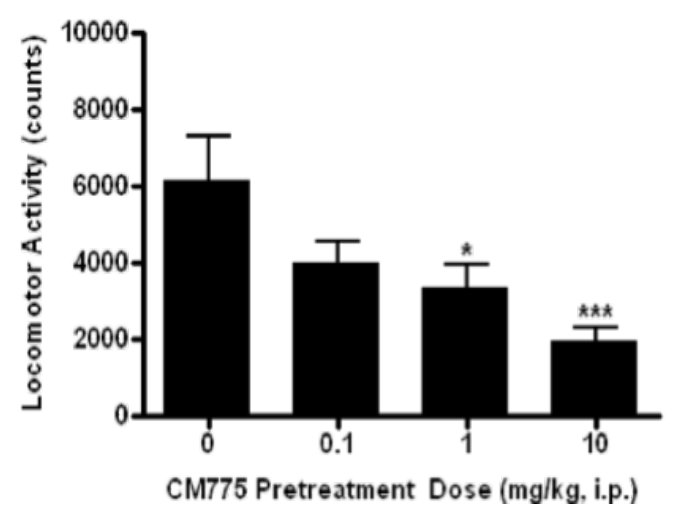

G

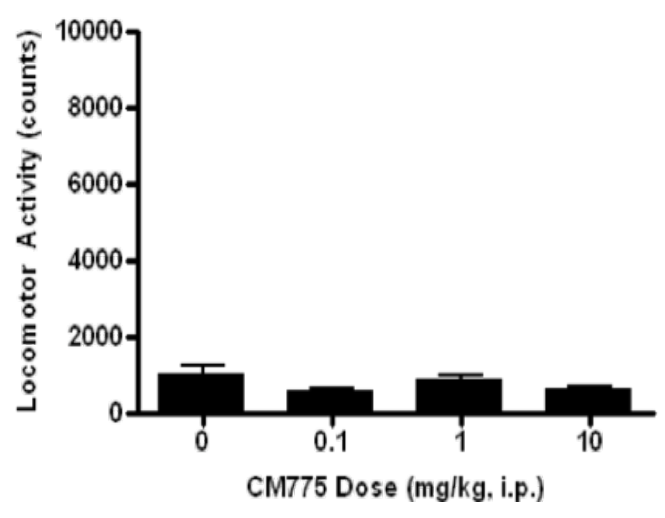

Fig. 6. The effects of cocaine, CM398, CM777, and CM775 on locomotor activity. Male, Swiss Webster mice were pretreated (i.p.) with saline, CM398, CM777, or CM775 prior to a stimulant dose of cocaine. A, Administration of cocaine $(0-30 \mathrm{mg} / \mathrm{kg}$, i.p.) produced a dose-dependent increase in locomotor activity. B, Pretreatment with CM398 (0-20 mg/kg, i.p.) significantly attenuated cocaine-induced hyperactivity. C, CM398 (0$20 \mathrm{mg} / \mathrm{kg}$, i.p.) alone produced no significant effect on locomotor activity. D, Pretreatment with CM777 (0-20 mg/kg, i.p.) significantly attenuated cocaine-induced hyperactivity. E, CM777 (0-20 mg/kg, i.p.) alone produced no significant effect on locomotor activity. F, Pretreatment with CM775 (0-10 mg/kg, i.p.) significantly attenuated cocaine-induced hyperactivity in a dose dependent manner G, CM775 (0-10 $\mathrm{mg} / \mathrm{kg}$, i.p.) alone produced no significant effect on locomotor activity. $\$ \$ \$ \mathrm{p}<0.001 \mathrm{vs}$. saline; ${ }^{*} \mathrm{p}<0.05,{ }^{* *} \mathrm{p}<0.01,{ }^{* * *} \mathrm{p}<0.001$ vs. cocaine $(30 \mathrm{mg} / \mathrm{kg})$; post-hoc Dunnet's. 


\section{DISCUSSION}

The binding data in this study revealed the novel compounds, CM699, CM398, CM777 and CM775, to have high affinity and are selective for sigma-2 receptors. These compounds have not only exhibited selectivity for sigma-2 receptors versus sigma-1 receptors, but also versus other non-sigma receptor sites, allowing their actions to be more confidently attributed to interaction with sigma-2 receptors. Previous compounds characterized as sigma-2 receptor ligand prove inadequate tools for studying the receptor. One reason is some of these compounds' display poor or moderate binding affinities $\left(\mathrm{K}_{\mathrm{i}}\right)$ for sigma-2 receptors. This also holds true for their selectivity for sigma-2 versus sigma-1 receptors. Additionally, the selectivity of the ligands for sigma-2 receptors against nonsigma sites is also largely problematic, with many of them exhibiting considerable affinities for various non-sigma sites. Moreover, numerous numbers of these sigma-2 receptor ligands do not even have, or report, data regarding their binding affinities to nonsigma sites. Due to the aforementioned issues of past sigma-2 receptor compounds, CM699, CM398, CM777 and CM775 are the best-suited pharmacological tools for studying the role of sigma-2 receptors in psychostimulant actions to date.

The binding affinities exhibited of the compounds' for both sigma subtypes in brain and liver tissue exhibited slight variations when compared. It is important to note that when comparing different data sets of ligand binding affinities at sigma-2 receptors variations in data can be seen. A putative explanation is because of sigma- 2 receptor localization in lipid rafts, which can impact the binding affinity of ligands for sigma-2 receptors. This is thought to be a result of variations in lipid compositions and associated proteins across different lipid rafts in tissues (Fishback, 2011). Yet, the data in this study exhibited strong correlations of the affinities for each receptor subtype in both liver and brain membrane with rank order being conserved. Thus, the results obtained are comparable at sigma-1 and sigma-2 receptors in both brain and liver membrane.

In the present study, behavioral tests showed the ability of CM398, CM777 and CM775 to attenuate cocaine-induced acute toxic and stimulant effects, while the CM699, exacerbated cocaine's acute toxic effects. Though the mechanism of action is unclear, it has been hypothesized to be a result of dopamine release modulation (Nuwayhid and Werling, 2006). The ability of CM398, CM777 and CM775 to attenuate cocaine-induced convulsions helped address the 'statement of problem' presented in this study. The higher selectivity and affinity of these compounds, versus previously proposed selective ligands, for sigma-2 provides more compelling support for the involvement of sigma-2 receptors in the convulsant actions of cocaine. CM777, compared to CM398 and CM775, showed more potent effect by protecting against the most convulsions at the lowest dose. A potential explanation is the better affinity of CM777 for 5- $\mathrm{HT}_{2}$, which has shown anticocaine effects when antagonized (McCracken et al., 1999). However, CM156, a previously characterized sigma ligand, with a similar sigma-2 receptor affinity to CM777 but much lower affinity for $5-\mathrm{HT}_{2}$ exhibited related protective effects against cocaineinduced convulsions (Xu et al., 2010). Therefore, CM777's interaction with 5- $\mathrm{HT}_{2}$ is unlikely to be the main mechanism of the compound's protective activity. Furthermore, CM156 has a >-500-fold affinity for sigma-1 receptors compared to CM777 but 
displayed a comparable dose response curve for cocaine-induced convulsions (Xu et al., 2010). This supports sigma- 2 receptors' role in CM777 anticonvulsant effects.

Sigma-1 receptor agonists are thought to serve a significant role in exacerbating cocaineinduced convulsions (Katz et al., 2011). Yet, a lack of information and understanding exists regarding the relevance of sigma-2 receptors in exacerbating cocaine convulsions, particularly compared to sigma-1 receptors (Matsumoto et al., 2001a). This is largely ascribed to a paucity in selective sigma receptor agonists, particularly for sigma-2. In the present study, pretreatment with CM699 in mice shifted the dose-response curve for cocaine-induced convulsions to the left. Furthermore, pretreatment with CM699 worsened cocaine toxicity, with some mice dying after administration of non-lethal doses of cocaine. These results reflect similar effects observed with the well-established sigma receptor agonist DTG (Matsumoto et al., 2002; McCracken et al., 1999). Though DTG is not selective for a particular sigma receptor subtype, it does serve as a comparison for putative sigma receptor agonists. Yet, since CM699 was unable to produce convulsions when administered alone and indicate CM699 similarity to positive allosteric modulators. Being that, to date, CM699 is one of the highest sigma-2 selective compounds (versus sigma-1), the data obtained suggests a specific contribution of this receptor subtype in worsening cocaine-induced convulsions. To confirm the results and effects seen with CM699, it is important to develop additional highly selective sigma-2, versus sigma-1, receptor putative agonists to use as pharmacological tools.

The ability of CM398, CM777 and CM775 to significantly alleviate cocaine-induced locomotor hyperactivity is congruent with previous studies implicating the sigma-2 subtype in mediating locomotion (Walker et al., 1993). Though the precise mechanism of sigma-2 in cocaine-induced hyperactivity remains unclear; it is thought that the receptor modulates dopamine in cocaine's locomotor actions (Walker et al 1993; Bastianetto et al., 1995; Nuwayhid and Werling, 2006; Garces-Ramirez et al., 2011). Fortunately, the compounds in the present study possess some of the highest affinities with the highest selectivity for the sigma-2 subtype and will be useful pharmacological tools in further characterizing sigma-2 effects and functions. Future studies to further distinguish functionality of the novel sigma- 2 selective ligands should be performed. Specifically, in vivo experiments looking at the effects of the sigma-2 ligands on apoptosis can help distinguish antagonistic/agonistic properties (Crawford and Bowen, 2002).

Though these ligands provide some of the best-suited pharmacological tools for studying sigma-2 receptors limitations still remain. Due to the involvement of sigma-2 receptors regulating cell life and death, this could have impacted some of the outcomes in the behavioral study, unknowingly. Additionally, a substantial drawback is the inability to confirm the effects on cocaine-induced behaviors seen with the selective sigma-2 ligands with knockdown and/or knockout of sigma-2 receptors. Regrettably, until this receptor subtype is sequenced this limitation will remain problematic. Even with that being said, the current study still provides the most compelling evidence of sigma- 2 receptors' involvement and specific contribution in the acute toxic and stimulant effects of cocaine to date. Further studies of the receptor subtype are needed better characterize its ability to modulate the actions of psychostimulants, and consequently, its potential as a therapeutic target in the development of pharmacotherapies for illicit drug use and abuse. 


\section{CONTRIBUTIONS}

Dr. Christophe Mésangeau and Dr. Christopher R. McCurdy at University of Mississippi synthesized CM699, CM398, CM777 and CM775.

Dr. James Fishback prepared the rat brain and liver $\mathrm{P}_{2}$ membrane and conducted saturation assays needed for the radioligand binding assay experiments.

Dr. Yantong Xu and Dr. Michael Seminerio performed sigma and non-sigma receptor radioligand binding assays using the conventional Brandel-based method.

Jason Healy performed radioligand binding assays for opioid receptors.

Colleen Beatty assisted with the CM777 cocaine-induced convulsion and locomotor activity experiments. 


\section{REFERENCE LIST}

Bastianetto S, Rouquier L, Perrault G and Sanger DJ (1995) DTG-induced circling behaviour in rats may involve the interaction between $\sigma$ sites and nigro-striatal dopaminergic pathways. Neuropharmacology 34: 281-287.

Berardi F, Ferorelli S, Abate C, Colabufo NA, Contino M, Perrone P and Tortorella V (2004) 4-(Tetralin-1-yl)- and 4-(naphthalen-1-yl)alkyl derivatives of cyclohexylpiperazine as receptor ligands with agonist $\sigma 2$ activity. $J$ Med Chem 47: 2308-2317.

Bowen W, de Costa BR, Hellewell SB, Walker JM and Rice KC (1993) $\left[{ }^{3} \mathrm{H}\right]-(+)-$ pentazocine: a potent and highly selective benzomorphan-based probe for sigma-1 receptors. Mol Neuropharmacol 3:117-126.

Bowen WD, Bertha CM, Vilner BJ and Rice KC (1995) CB-64D and CB-184: ligands with high sigma-2 receptor affinity and subtype selectivity. Eur J Pharmacol 278: $257-260$.

Bowen WD (2000) Sigma receptors: recent advances and new clinical potentials. Pharmaceutica Acta Helvetiae 74: 211-218.

Bowen WD (2007) o2 Receptors: regulation of cell growth and implications for cancer diagnosis and therapeutics, in Sigma Receptor Chemistry, Cell Biology, and Clinical Implications (Matsumoto RR, Bowen WD, and Su T eds) pp 1-23, Springer, New York.

Carroll FI, Howell LL and Kuhar MJ (1999) Pharmacotherapies for treatment of cocaine abuse: preclinical aspects. $J$ Med Chem 42: 2721-2736

Chaki S, Tanaka M, Muramatsu M and Otomo S (1994) NE-100, a novel potent sigma ligand, preferentially binds to sigma-1 binding sites in guinea pig brain. EurJ Pharmacol 251: R1-R2.

Chu W, Xu J, Zhou D, Zhang F, Jones LA, Wheeler KT and Mach RH (2009) New Nsubstituted 9-azabicyclo[3.3.1]nonan-3a-yl phenylcarbamate analogs as $\mathrm{r}^{2}$ receptor ligands: sythesis, in vitro characterization, and evaluation as PET imaging and chemosensitization agents. Bioorg and Med Chem 17: 1222-1231.

Crawford KW and Bowen WD (2002) Sigma-2 receptor agonists activate a novel apoptotic pathway and potentiate antineoplastic drugs in breast tumor cell lines. Cancer Res 62: 313-322.

Crawford KW, Coop A and Bowen WD (2002) sigma-2 Receptors regulate changes in sphingolipid levels in breast tumor cells. Eur J Pharmacol 443: 207-209.

Garces-Ramirez L, Green JL, Hiranita T, Kopajtic TA, Mereu M, Thomas AM, Mesangeau C, Narayanan S, McCurdy CR, Katz JL and Tanda G (2011) Sigma receptor agonists: receptor binding and effects on mesolimbic dopamine neurotransmission assessed by microdialysis. Biol Psychiatry 69: 208-211.

Gebreselassie D and Bowen WD (2004) Sigma-2 receptors are specifically localized to lipid rafts in rat liver membranes. Eur J Pharmacol 493: 19-28.

Guitart X, Codony X and Monroy X (2004) Sigma receptors: biology and therapeutic potential. Psychopharmacology 174: 301-319.

Hanner M, Moebius FF, Flandorfer A, Knaus HG, Striessnig J, Kempner E and Glossman $\mathrm{H}$ (1996) Purification, molecular cloning, and expression of the mammalian sigma-1-binding site. Proc Natl Acad Sci U S A 9: 8072-8077. 
Hashimoto K and Ishiwata K (2006) Sigma receptor ligands: possible application as therapeutic drugs and radiopharmaceuticals. Curr Pharm Des 12: 3857-3876.

Hayashi T and Su TP (2003) Intracellular dynamics of sigma-1 receptors (sigma-1 binding sites) in NG108-15 cells. J Pharmacol Exp Ther 306: 726-733.

Hayashi T and Su TP (2007) Sigma-1 receptor chaperone at the ER-mitochondrion interface regulate $\mathrm{Ca}^{2+}$ signaling and cell survival. Cell 131:596-610.

Hellewell SB and Bowen WD (1990) A sigma-like binding site in rat pheochromocytoma (PC12) cells: decreased affinity for (+)-benzomorphans and lower molecular weight suggest a different sigma receptor form from that guinea pig brain. Brain Res 527: 244-253.

Hiranita T, Soto PL, Tanda G and Katz JL (2010) Reinforcing effects of $\sigma$-receptor agonists in rats trained to self-administer cocaine. $J$ Pharmacol Exp Ther 332: 515-524.

Hornick JR, Xu J, Vangveravong S, Tu Z, Mitchem JB, Spitzer D, Goedegebuure P, Robert H, Mach RH and Hawkins WG (2010) The novel sigma-2 receptor ligand SW43 stabilizes pancreas cancer progression in combination with gemcitabine. Molecular Cancer 9: 298-309.

Itzhak Y, Martin JL, Ali SF and Norenberg MD (1997) Depletion of striatal dopamine transporter does not affect psychostimulant-induced locomotor activity. Neuroreport 8, 3245-3249.

Izenwasser S, Thompson-Montgomery D, Deben SE, Chowdhury IN and Werling LL (1998) Modulation of amphetamine-stimulated (transporter mediated) dopamine release in vitro by $\sigma-2$ receptor agonists and antagonists. Eur J Pharmacol 346: 189-196.

Katz JL, Su TP, Hiranita T, Hayashi T, Tanda G, Kopajtic T and Tsai SY (2011) A role for sigma receptors in stimulant self administration and addiction. Pharmaceuticals 4: 880-914.

Kekuda R, Prasad PD, Fei YJ, Leibach FH and Ganapathy V (1996) Cloning and functional expression of the human type $1 \sigma$ receptor (hSigma R1). Biochem Biophys Res Commun 229: 553-558.

Kita K, Kurita T and Ito M (2001) Characterization of the reversible nature of the reaction catalyzed by sphingolipid ceramide N-deacylase: a novel form of reverse hydrolysis reaction. Eur J Biochem 268: 592-602.

Martin WR, Eades CG, Thompson JA, Huppler RE and Gilbert PE (1976) The effects of morphine- and nalorphine- like drugs in the nondependent and morphinedependent chronic spinal dog. J Pharmacol Exp Ther 197: 517-532.

Matsumoto RR, Hemstreet MK, Lai NL, Thurkauf A, De Costa BR, Rice KC, Hellewell SB, Bowen WD and Walker JM (1990) Drug specificity of pharmacological dystonia. Pharmacol Biochem Behav 36:151-155.

Matsumoto RR, Bowen WD, Tom MA, Vo VN, Truong DD and De Costa BR (1995) Characterization of two novel $\sigma$ receptor ligands: antidystonic effects in rats suggest $\sigma$ receptor antagonism. Eur J Pharmacol 280: 301-310.

Matsumoto RR, McCracken KA, Pouw B, Miller J, Bowen WD, Williams W and DeCosta BR (2001) N-alkyl substituted analogs of the $\sigma$ receptor ligand BD1008 and traditional $\sigma$ receptor ligands affect cocaine-induced convulsions and lethality in mice. Eur J Pharmacol 411: 261-273. 
Matsumoto RR, McCraken KA, Pouw B, Zhang Y and Bowen WD (2002) Involvement of sigma receptors in the behavioral effects of cocaine: evidence from novel ligands and antisense oligodeoxynucleotides. Neuropharmacology 42: 1043-1055.

Matsumoto RR, Liu Y, Lerner M, Howard EW and Brackett DJ (2003) б Receptors: potential medications development for anti-cocaine agents. Eur J Pharmacol 469: $1-12$.

Matsumoto RR (2007) o Receptors: historical perspective and background, in Sigma Receptor Chemistry, Cell Biology, and Clinical Implications (Matsumoto RR, Bowen WD, and Su T eds) pp 1-23, Springer, New York.

Matsumoto RR, Pouw B, Mack AL, Daniels A and Coop A (2007) Effects of UMB24 and $( \pm)$-SM 21, putative $\sigma_{2}$-preferring antagonists, on behavioral toxic and stimulant effects of cocaine in mice. Pharmacol Biochem Behav 86: 86-91.

Matsumoto, RR (2009) Targeting sigma receptors: novel medication development for drug abuse and addiction. Expert Rev Clin Pharmacol 2: 351-358.

Maurice T, Martin-Fardon R, Romieu P and Matsumoto RR (2002) Sigma(1) (sigma(1)) receptor antagonists represent a new strategy against cocaine addiction and toxicity. Neurosci Biobehav Rev. 26:499-527

McCracken KA, Bowen WD, de Costa BR and Matsumoto RR (1999) Two novel $\sigma$ receptor ligands, BD1047 and LR172, attenuate cocaine-induced toxicity and locomotor activity. Eur J Pharmacol 370: 225-232.

Mendelsohn LG, Kalra V, Johnson BG and Kerchner GA (1985) Sigma opioid receptor: characterization and co-identity with the phencyclidine receptor. J Pharmacol Exp Ther 233: 597-602.

Mesangeau C, Narayanan S, Green AM, Shaikh J, Kausahl N, Viard E, Xu Y-T, Fishback JA, Poupaert JH, Matsumoto RR and McCurdy CR (2008) Conversion of a highly selective sigma-1 receptor-ligand to sigma-2 receptor preferring ligands with anticocaine activity. J Med Chem 51: 1482-1486.

Narayanan S, Mesangeau C, Poupaert JH and McCurdy CR (2011) Sigma receptors and cocaine abuse. Curr Top Med Chem 11: 1128-1150.

Newman AH and Coop A (2007) Medicinal chemistry: new chemical classes and subtype-selective ligands, in Sigma Receptor Chemistry, Cell Biology, and Clinical Implications (Matsumoto RR, Bowen WD, and Su T eds) pp 1-23, Springer, New York.

NIDA (2010) Research Report Cocaine. Bethesda, MD: NIDA; NIH Pub Number 104166.

Nuwayhid S and Werling LL (2006) Sigma-2 $\left(\sigma_{2}\right)$ receptors as a target for cocaine action in the rat striatum. Eur J Pharmacol 535: 98-103.

Office of National Drug Control Policy (2004) The economic cost of drug abuse in the United States, 1992-2002. Pub Number 207303, Executive Office of the President, Washington, DC.

Robson MJ, Noorbakhsh B, Seminerio MJ and Matsumoto RR (2012) Sigma-1 receptors: potential targets for the treatment of substance abuse. Curr Pharml Des 18: $902-919$.

Romieu P, Martin-Fardon R and Maurice T (2000). Involvement of the sigma1 receptor in the cocaine-induced conditioned place preference. Neuroreport 11: 2885-8.

$\mathrm{Su}$ TP (1982) Evidence for sigma opioid receptor: binding of $\left[{ }^{3} \mathrm{H}\right] \mathrm{SKF}-10047$ to 
etorphine-inaccessible sites in guinea-pig brain. J Pharmacol Exp Ther 223: 284290.

Tilley MR, O'Neil B, Han DD and Gu HH (2009) Cocaine does not produce reward in absence of dopamine transporter inhibition. Neuroreport 20: 9-12.

$\mathrm{Tu} Z$, Xu J, Jones LA, Li S, Dumstorff C, Vangveravong S, Chen DL, Wheeler KT, Welch MJ and Mach RH (2007) Fluorine-18-labeled benzamide analogues for imaging the $\sigma_{2}$ receptor status of solid tumors with positron emission tomography. J Med Chem 50: 3194-3204.

Vilner BJ and Bowen WD (1999) Modulation of cellular calcium by sigma-2 receptors: release from intracellular stores in human SK-N-SH neuroblastoma cells. JPET 292: $900-911$.

Walker JM, Bowen WD, Patrick SL, Williams WE, Mascarella SW, Bai X and Carroll FI (1993) A comparison of (-) -deoxybenzomorphans devoid of opiate activity with their dextrorotatory phenolic counterparts suggests role of $\sigma_{2}$ receptors in motor function. Eur J Pharmacol 231: 61-68.

Wong EH, Knight AR and Woodruff GN (1988) [ $\left.{ }^{3} \mathrm{H}\right] \mathrm{MK}-801$ labels a site on the Nmethyl-D-aspartate receptor channel complex in rat brain membranes. $J$. Neurochem 50:274-281.

Xu J, Zeng C, Chu W, Pan F, Rothfuss JM, Zhang F, Tu Z, Zhou D, Zeng D, Vangveravong S, Johnston F, Spitzer D, Chang KC, Hotchkiss RS, Hawkins WG, Wheeler KT and Mach RH (2011) Identification of the PGRMC1 protein complex as the putative sigma-2 receptor binding site. Nature Communications 2: 380 .

Xu YT, Kaushal N, Shaikh J, Wilson LL, Mesangeau C, McCurdy CR and Matsumoto RR (2010) A novel substituted piperazine, CM156, attenuates the stimulant and toxic effects of cocaine in mice. J Pharmacol Exp Ther 333: 491-500. 


\title{
VII. CURRICULUM VITAE
}

\section{Bahar Noorbakhsh}

West Virginia University School of Pharmacy, 1 Medical Center Drive, Morgantown, WV 26506

Phone: (724) 494-8880, Email: bnoorbak@gmail.com

Seeking a position as a clinical research associate in order to utilize my strong analytical, research and communication skills combined with a Master of Science in Biomedical

Sciences, emphasis in Pharmaceutical and Pharmacological Sciences.

\section{EDUCATION}

2005-2009 Allegheny College, Meadville, PA

B.S. Behavioral Neuroscience

2009-2012 West Virginia University, Morgantown, WV

M.S. Biomedical Science (expected graduation Aug 2012)

Concentration: Pharmaceutical and Pharmacological Sciences

\author{
RESEARCH EXPERIENCE \\ 2009-2012 West Virginia University- Morgantown, WV \\ Research Assistant; Graduate Student \\ $2007 \quad$ Allegheny College- Meadville, PA \\ Undergraduate Research Assistant \\ RELEVENT EXPERIENCE \\ 2011 Chestnut Ridge Center- Morgantown, WV \\ Extern: Intensive Outpatient Program (IOP) \\ 2008 Wesbury- Meadville, PA \\ Personal Care Assistant (PCA) \\ 2004 VA Butler Healthcare- Butler, PA \\ Volunteer \\ ORGANIZATIONS/LEADERSHIP \\ 2011-2012 Society for Neuroscience \\ Reactivated Regional Student Chapter at West Virginia University \\ 2011-2012 West Virginia University Health Sciences Graduate Student \\ Organization (GSO) \\ Secretary (2011); Vice President (2012) \\ 2010-2011 American Association for Pharmaceutical Scientists (AAPS) \\ Vice Chair of Student Chapter at West Virginia University
}

\section{PEER REVIEWED PUBLICATIONS}

1. Robson MJ, Noorkbakhsh B, Seminerio MJ, Matsumoto RR (2011) Sigma-1 receptors: potential targets for the treatment of substance abuse. Curr Pharm Des 18:902-919 
2. Noorbakhsh B, Seminerio MJ, Kaushal N, Xu YT, Healy JR, Mesangeau C, McCurdy CR, Matsumoto RR (2012) Pharmacolgoical characterization of sigma-2 preferring compounds: modulation of psychostimulant-induced effects. JPET, In preparation.

3. Stavitskaya $\mathrm{L}^{*}$, Seminerio $\mathrm{MJ}^{*}$, Noorkbakhsh B, Healy J, Bowen W, Matsumoto RR, Coop A (2012) The effect of partial opioid structures on sigma receptors. J Med Chem, In preparation.

\section{ABSTRACTS/POSTER PRESENTATIONS (SELECTED)}

1. Wiseman AL, Schellberg A, Noorbakhsh B, Erbelding $L$ (2009) Training older adults to reduce false recognition. Eastern Psychological Association Annual Meeting, Pittsburgh, PA. (poster presentation)

2. Noorbakhsh B, Seminerio MJ, Robson MJ, Matsumoto RR, McCurdy CR (2011) CM777, selective sigma-2 ligand: a putative treatment for attenuation of cocaineinduced behavior. STEM, Morgantown, WV. (poster presentation)

3. Noorbakhsh B, Seminerio MJ, Xu YT, Mesangeau C, McCurdy CR, Matsumoto RR (2011) Synthesis and pharmacological characterization of sigma-2 preferring compounds: implications for cocaine-induced behaviors. Society for Neuroscience, Washington D.C. (poster presentation)

4. Noorbakhsh B, Seminerio MJ, Xu YT, Mesangeau C, McCurdy CR, Matsumoto RR (2011) Pharmacological characterization of sigma-2 preferring compounds: implications for cocaine-induced behaviors. Appalachian Health Summit, Lexington, KY. (poster presentation)

5. Noorbakhsh B, Seminerio MJ, Xu YT, Mesangeau C, McCurdy CR, Matsumoto RR (2011) Characterization of sigma-2 preferring compounds: implications for cocaineinduced behaviors. STaR Symposium and Meeting of the West Virginia Academy of Science, Huntington, WV. (poster presentation)

\section{PROFESSIONAL SOCIETY MEMBERSHIPS}

- American Association for Pharmaceutical Scientists (AAPS)

- International Drug Abuse Research Society (IDARS)

- Society for Neuroscience

\section{AWARDS}

- West Virginia University School of Pharmacy Travel Award, 2011

- E.J. Van Liere Memorial Convocation Poster Presentation Award - First Place, 2012

- STaR Symposium and Meeting of the West Virginia Academy of Science Graduate Student Poster Presentation Award- First Place, 2012 


\title{
VIII. APPROVAL PAGE
}

Pharmacological Characterization of Sigma-2 Preferring Compounds:

Implications in Cocaine-induced Behaviors

\author{
Bahar Noorbakhsh
}

Thesis submitted to the School of Pharmacy at West Virginia University in partial fulfillment of the requirements for the degree of Master of Science in Biomedical Sciences

Department of Pharmaceutical and Pharmacological Sciences

APPROVAL OF THE EXAMINING COMMITTEE

William Petros, Pharm.D.

Carl R. Sullivan, M.D.

Rae R. Matsumoto Ph.D., Chair

Date 